دراسه تحليليه للأزياء الشعبيه فى منطقه برج العرب بمحافظة الإسكندرية والإستفاده منها فى اقتباس أزياء نسائيه معاصره

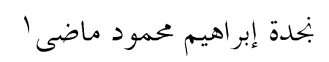

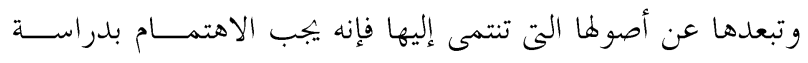

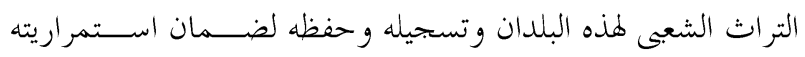

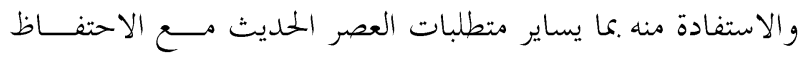

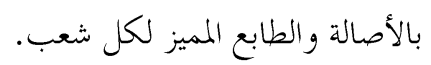

فدراسة الزى ومكملاته كفن من الفنون يعتبر جزء لا يتجزأ

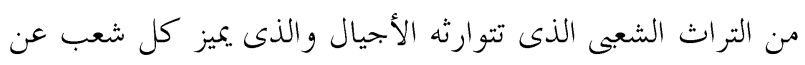

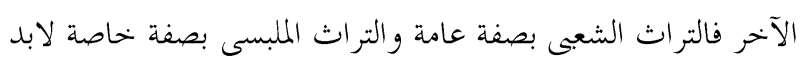

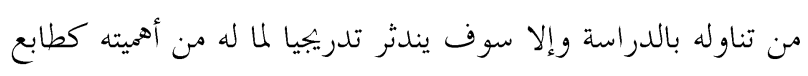

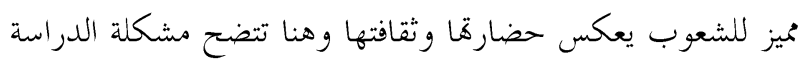

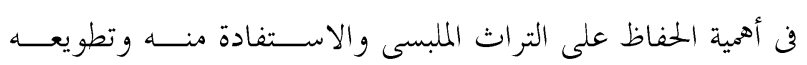
وتوظيفه في تصميمات فنية حديثة تساير التطورات المعاصرة للفنون المختلفة.

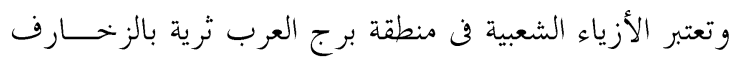

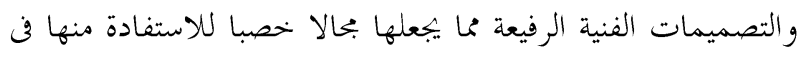

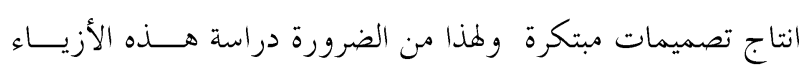

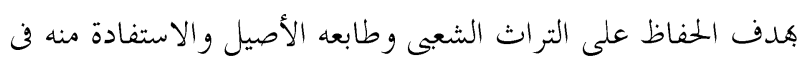

$$
\text { تصميم أزياء عصرية. }
$$

الملامح العامة لمنطقة الدراسه

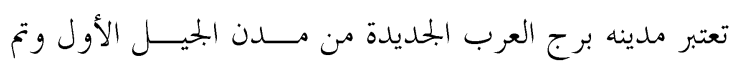

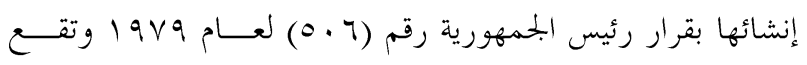

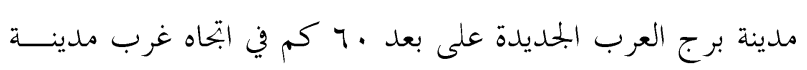

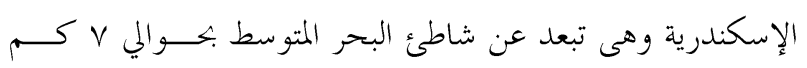

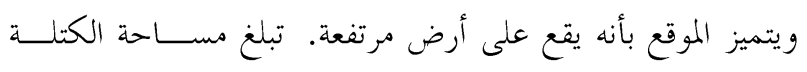

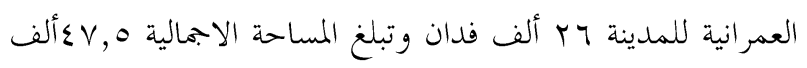

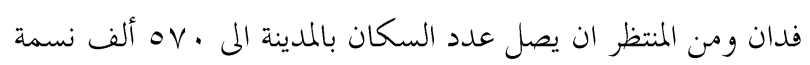
عند أكتمال نموها (Www.urban-comm.gov.eg).

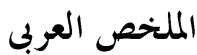

نلقى الضوء على جزء هام من تراثنا المصرى ممثل في منطقة هامة وهى منطقة برج العرب بالاسكندرية من خلال دراسة مأل الأنماط الأزياء

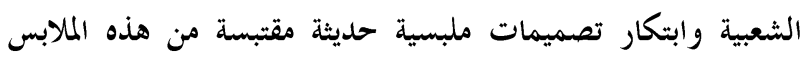
الشعبية ومكملاقة بما فيها من زخارف لاثراء تلك التصميمات. وقد اتبع البحث المنهج التاريخى الوصفى واستخدمت الباحثة

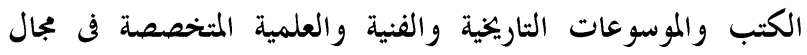
البحث حيث تم رسم عشر تصميمات مبتكرة مقتبسة من الأزياء الشعبية في منطقة البحث واضافة التأثيرات و والزخارف والاكسسوارات اللازمة لم .

\section{المقدمــــــة والمثكلة البحثية}

لا شك أن الحضارة في العصر الحديث لا تخرج فن مظهرهـ

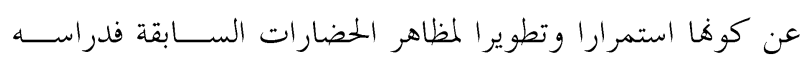

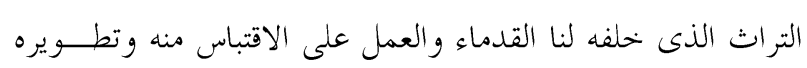

$$
\text { يعتبر رمزا للحضارة. }
$$

ويعد التراث الشعبي مرآة فهو صورة نابضة عن حياة الشعوب

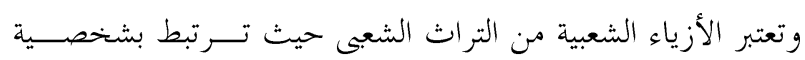

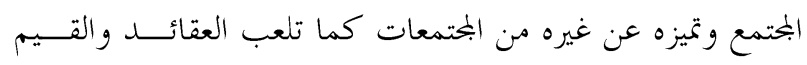

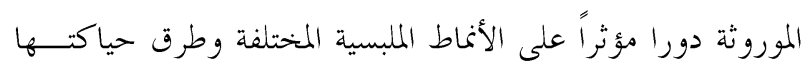

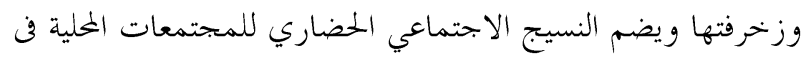

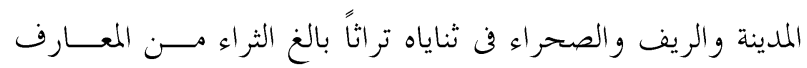

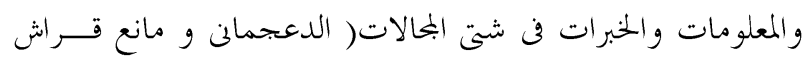
(ه) 々) \&،

وخوفا من ضياع السمات التي تميز هذه الجتمعات العربية عن

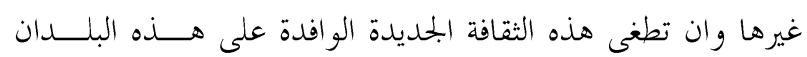

'مدرس بقسم الاقتصاد المتزلم- ملابس ونسيج- كلية التربيه النوعيه-بامعة الاسكندرية

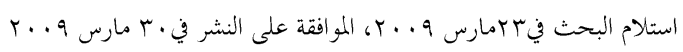


السياحية من خامات مختلفة كالجلدا والقماش وعجينة الورق مــع الاستعانة بالخامات المساعدة.

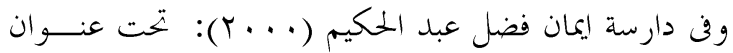
"دراسة ميدانية لانماط الزخرفة بمنطقة جنوب سيناء وراس والاستفادة منها

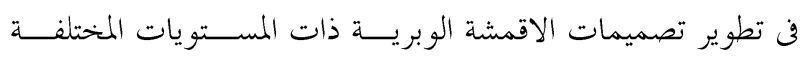

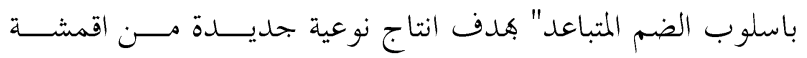

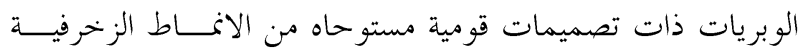

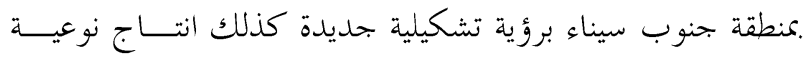

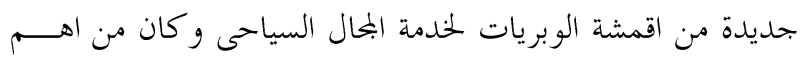

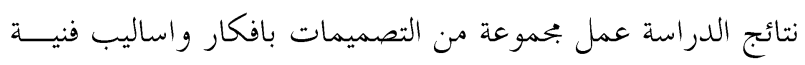

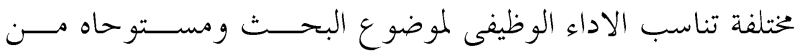

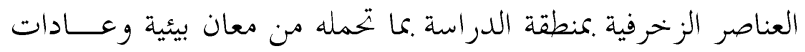
و تقاليد لهذه المنطقة مما يدل على ارتباط الاصالة بالمعاصرة.

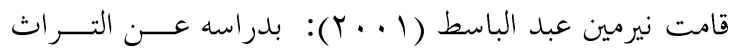

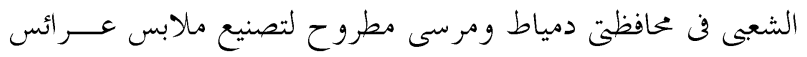

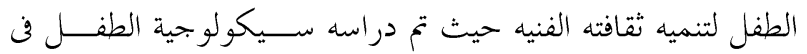

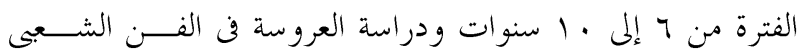

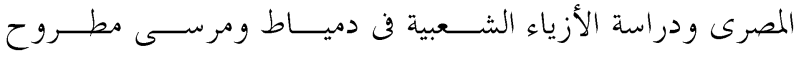

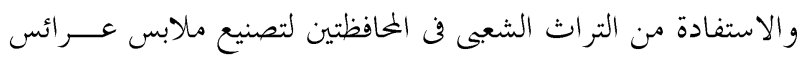

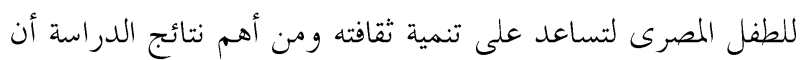

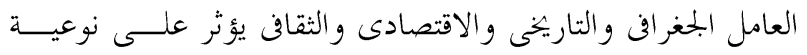

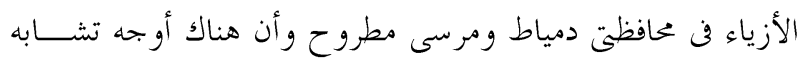

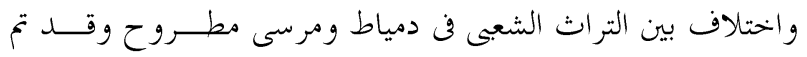
تنفيذ عرائس من القماش وعمل تصميمات مقترحة لهذه العــــائس مستبطة من التراث الشعبى الملبسى لمحافظتى دمياط ومرسى مطروح.

\section{أهداف البحث}

1 - دراسة تحليلية للأزياء الشعبية فن منطقة برج العرب. ץ- الاستفادة من التراث الشعبى لملابس منطقة برج العرب لتصنيع ملابس معاصرة. ب- تزويد المكتبة العربية بدراسة علمية متخصصة عــن التــراث الشعى لتسجيله.
قامت سعدية الحداد ( 9 (191): بدراسه عن احياء التــراث

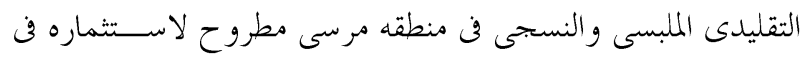

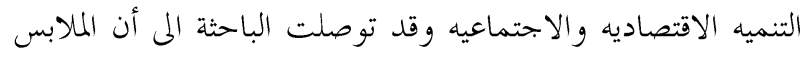
التقليدية للبدويات تتمثل في الثوب وتصمم بوسط و كشكشه كما

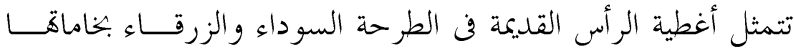

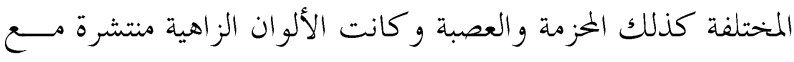

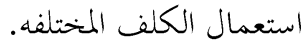
وتوصى بانه لابد من اقتناء كل ما يمكن جمعه من قطع التراث المختلفة والمتوفرة في الاسواق الشعبية في المدن والقرى ووضعها في

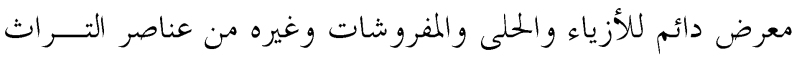

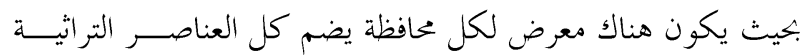
المتعلقة هـا.

وتوضح منى حافظ صدقى (919 ()): في دراسه عن "العوامل

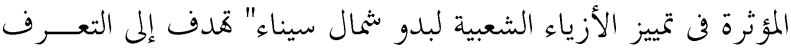
على الأزياء البدوية في سيناء وإظهار جوانب الابداع بها كما تناول

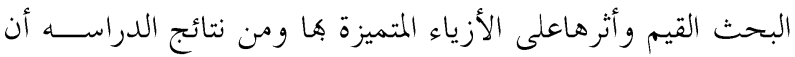

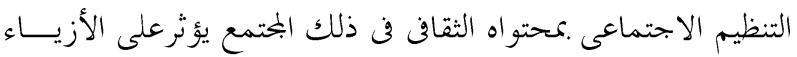
من حيث الخامة والأشكال الزخرفية.

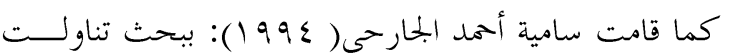
فيه تأثير الحضارات المختلفة على الأزياء وزخارفها في جنوب سيناء من خلال العوامل الجغرافية والتاريخية والاجتماعية والثقافية وأثرها

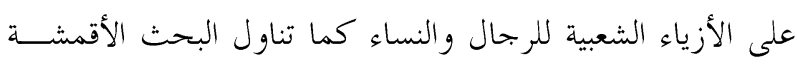
والزخارف والخامات المستخدمة في زخرفة الأزياء الشعبية بســيناء ومن نتائج البحث وجود نمط معين من الأزياء الشعبية بسيناء ناتج عن تفاعل العو امل الجغر افية والتاريخية والاجتماعية والثقافية. وفن دراسه اخرى لنفس الباحثــهـ (999 (1): عــن إمكانيــة

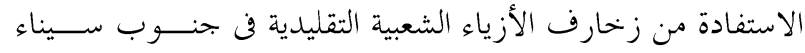
لعمل نماذج متميزة من العرائس لتلائم بجال السياحة في مصر قامت

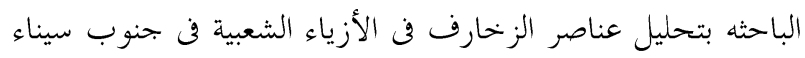
ودراسة أساليب تنفيذها والاستفادة من زخحارف الأزياء الشــعبية لتشكيل عرائس متميزة كتذكارات سياحية تحمل الموروثات الثقافية للحنوب سيناء ومن أهم نتائج الدراسة عمل بحموعة من العــــائس 
تحمل ملامح المصدر الاصلى (بنوى شكرى و ســلوى هنـــى،

كما هو ميلاد فكرة جديدة من خلال واقع ملموس أو غسير

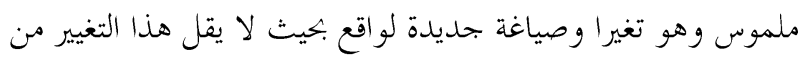

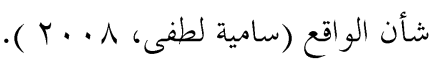

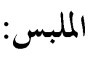

تعنى الهيئة أو المنظر وجمعها ملابس (إبراهيم مصطفى وآخرون، 970 (19) وفى تعريف آخرهو كل ما يرتديه الفرد سواء كان داخليا أو خارجيا (لويس معلوف، (1991 ()).

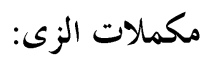

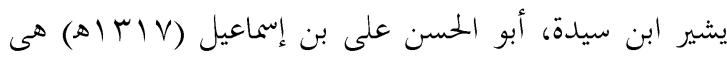

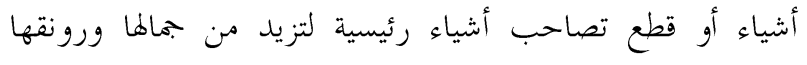
و تشمل مكملات الزى وحقائب اليد والأحذية والأحزمة وأغطية

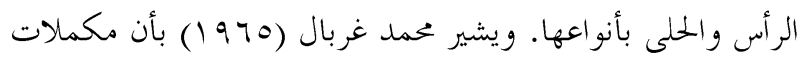
الزينة تطلق على الاضافات التى تضاف للملبس وتؤدى الم اظهار

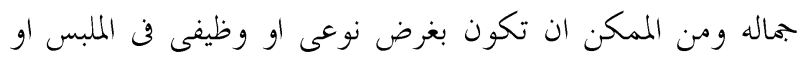
بغرض جمالى فقط.

ويشير منير البعليكى (997 1997) بأن المكملات يطلق عليها

اسم( accessory ) معنى اها شىء كمالى يضاف للز ينه وما اليها.

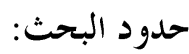

$$
\text { 1 - الأزياء الشعبية في منطقة برج العربح. }
$$

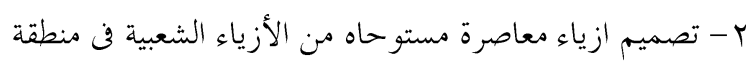

$$
\text { برج العرب. الأسلوب البحثي }
$$

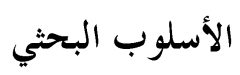

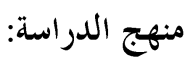

تتبع هذه الدراسة المنهج التاريخى الوصفى التحليلى والمنـــهج التطبيقى للأزياء الشعبية فن منطقة برج العرب.

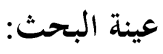
1 - العينة البشرية: عينة عمديه من حملة التراث ممن لديهم المقدرة على تحقيق أغراض الدراسة.
هى امرأة تعيش فن نظام الرعى والمر أة البدوية تشارك الرجـــل

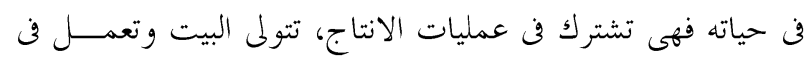

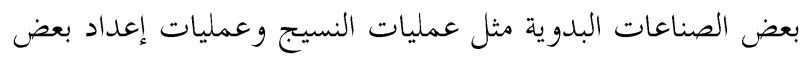

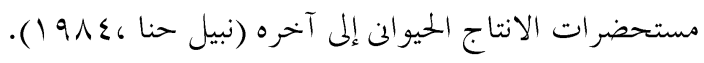

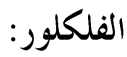
وهو التراث الذى انتقل من شخص إلى شخص آخر وجرى

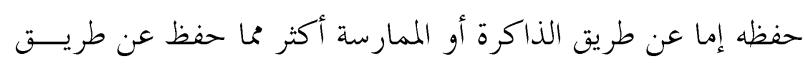

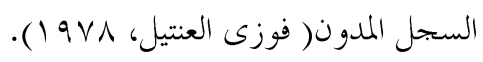

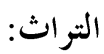

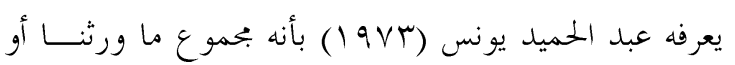

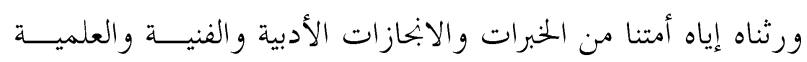

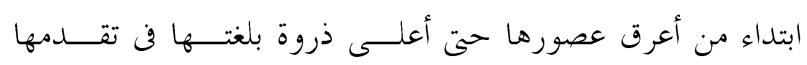
الخضارى.

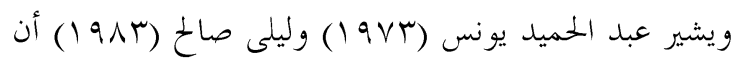

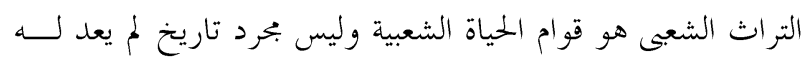
وظيفة تلائم الحياة العصرية المتطورة فهو الحصيلة الثقافية لأجيــال متعددة من بيئات ومراحل مختلفة وهو يربط الحاضر بالماضى ويبشر

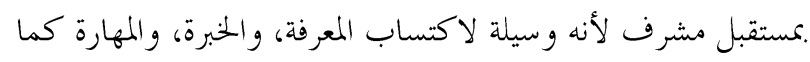

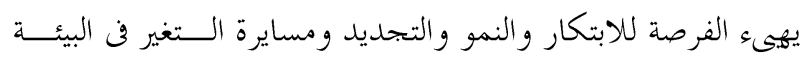
المادية للمواطنين. ويوضح لويس معلوف (1991) بأنه هو ما يخلفــهـ الرجـــل

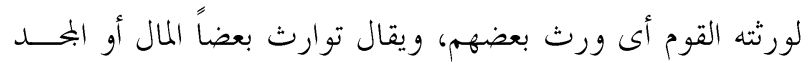

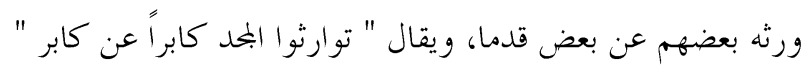
المحد متو ارث بينهم.

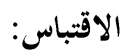
هو عمليه تفاعل بين مصمم الازياء وأحد مصادر التصــميم

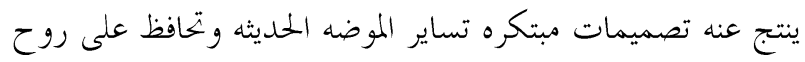

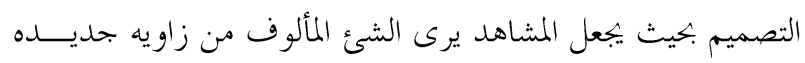


نجدة إبر اهيم محمود ماضى: دراسه تحليليه للأزياء الشعبيه فن منطقه برج العرب بكحافظة الأسكندرية والأستفاده منها لإقتباس أزياء نسائيه معاصره

تم استخدام معامل الثبات" لالفالكرونباخ" حيث اقتربت القيمة من الواحد الصحيح وهى تعتبر قيمه دليه احصائياً. عينة البحث:

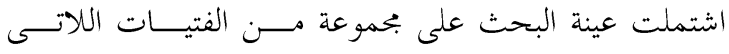

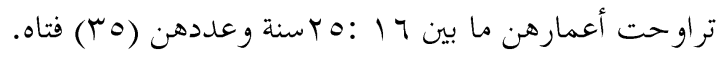

\section{النتائج البحثية ومناقشتها}

أولا:- - الدراسه التحليليه للازياء الشعبيه بمنطقه البحث: 1 - إناصر التصميم في الأزياء الشعبيه

الخامات

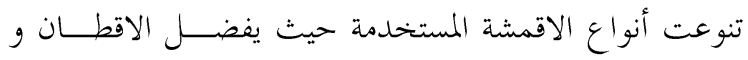

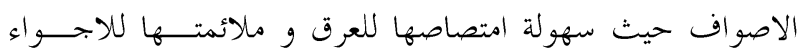

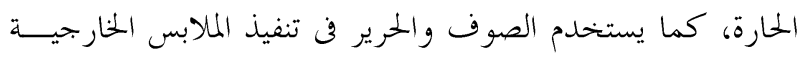

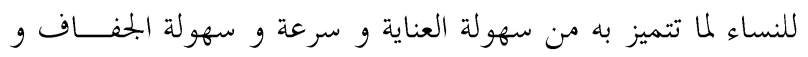
مقاومتها للكرمشة. الخامات المساعدة القيطان يستخدم زخرفة بعض الملابس مثل الصديرى. الحرز والترتر

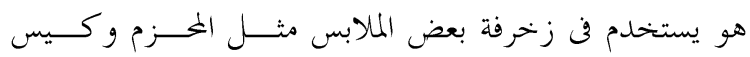
المكحلة. الألو ان

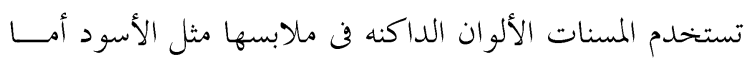
الفتيات فيستخدمن الالوان الزاهية مثل الاحمر و الاخضر و الازرق

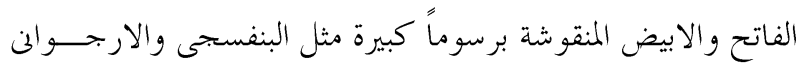

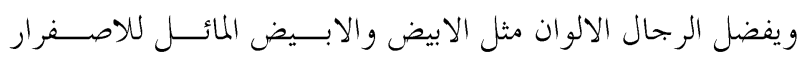

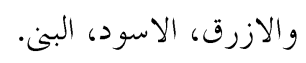
الخطوط و الاشكال اتضح وجود الخطوط المنحنية بكثرة كما في الجرد حيث ترمز

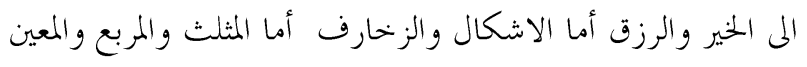

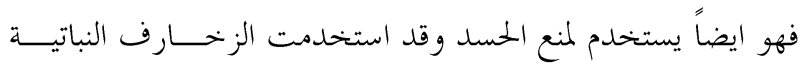

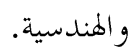

r- العينة المادية: بحموعة من الملابس التراثية ومكمالاتها ترتـــيها سيدات برج العرب والتى تعتبر من المصادر الأولية للبيانات.

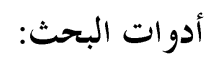

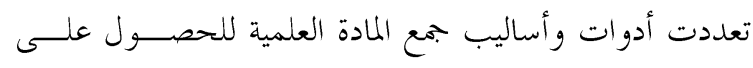

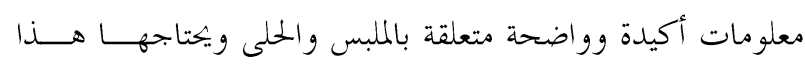
النوع من الأبحاث من أهمها:

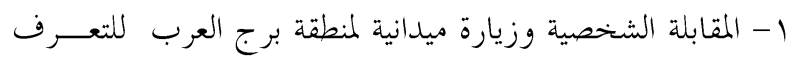
على أنماط الأزياء الشعبية. r- الملاحظة وتسجيل الأزياء الشعبية بالتصوير الفوتوغر افى.

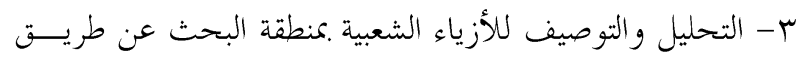

$$
\text { التصوير الفوتوغر افى. }
$$

استبانة لقياس أراء الفتيات ومدى تقبلهن للتصميمات المقترحة: تم تصميم استبانة لقياس آراء الفتيات في التصميمات المقترحة

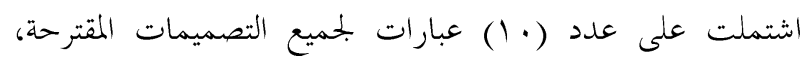

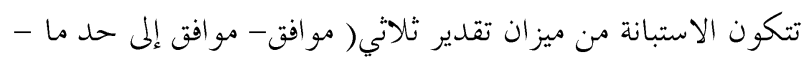

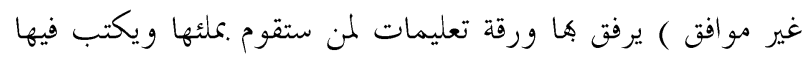
الهدف من البحث، الاسم، السن. تصحيح الاستبانة: تم تصحيح الاستبانة عن طريق حساب التكرارات و النســبـ

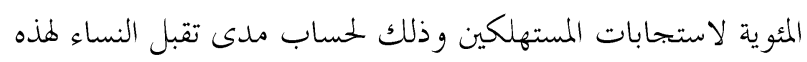

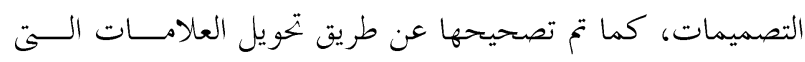

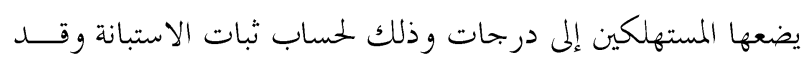
تم وضع ثلاث درجات لخانة "موافق"، ودرجتان لخانة " موافق إلى ولى

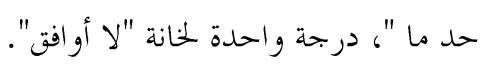
صدق الاستبانة: تم التأكد من صدق الاستبانة عن طريق صدق الختــوى مــن

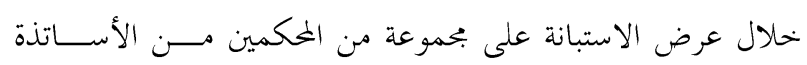

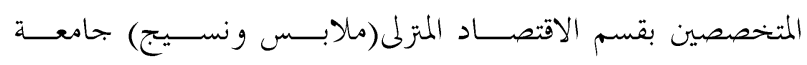

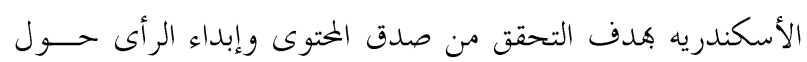

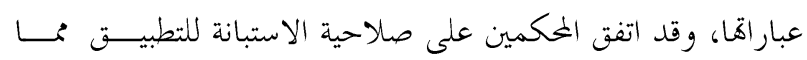
يؤ كد صدقها.

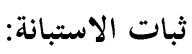




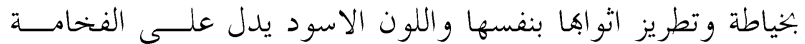

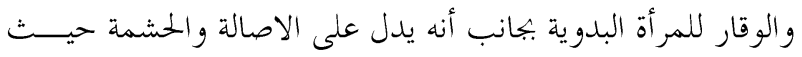

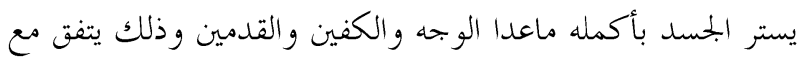
الدين والتراث العربى صوره رقم (؟).

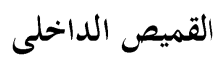
ترتدى المرأة البدوية قميصاً داخليًاً تحت الثوب الخارجى

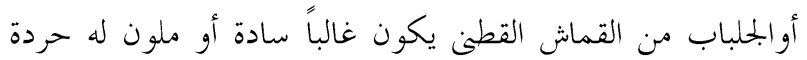

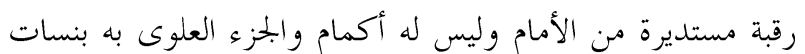

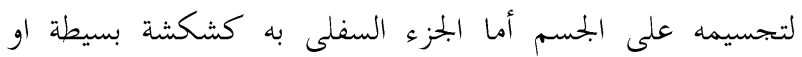
كسر ات.

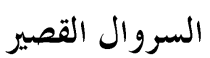
يصنع السروال من قماش قطنى خام أوابيض اوملون ويتكون

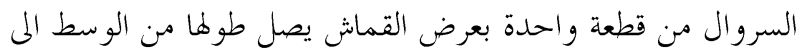
نصف الفخذ ويثبت في الوسط بواسطة استيك. r - دراسه لملابس السيدات بمنطقة البحث الجلباب

وترتديه البدوية داخل البيت وقد ترتدى البدويسـة جلبابـــــأو

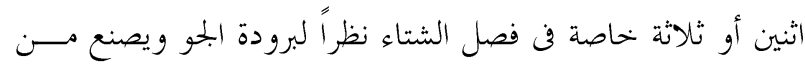

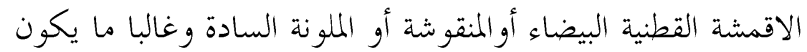

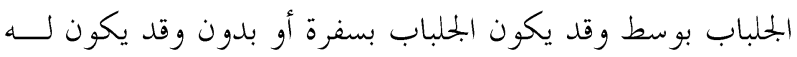

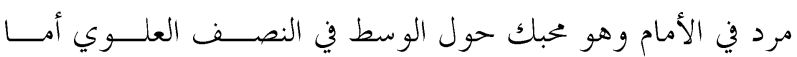

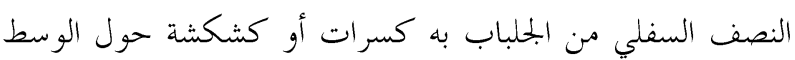
وقد تحلي أطراف الجلباب بشر ائط من الدانتيل أو الزجزاج صــــوره رقم (1) - (1) - (1) الثوب

ترتدى المرأة البدوية الثوب خارج المتزل وغالباً ما يكون بلون

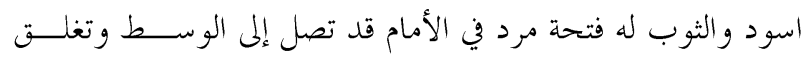

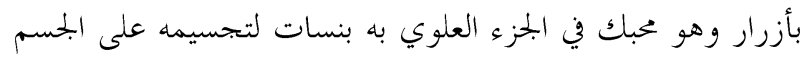

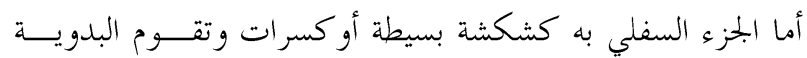

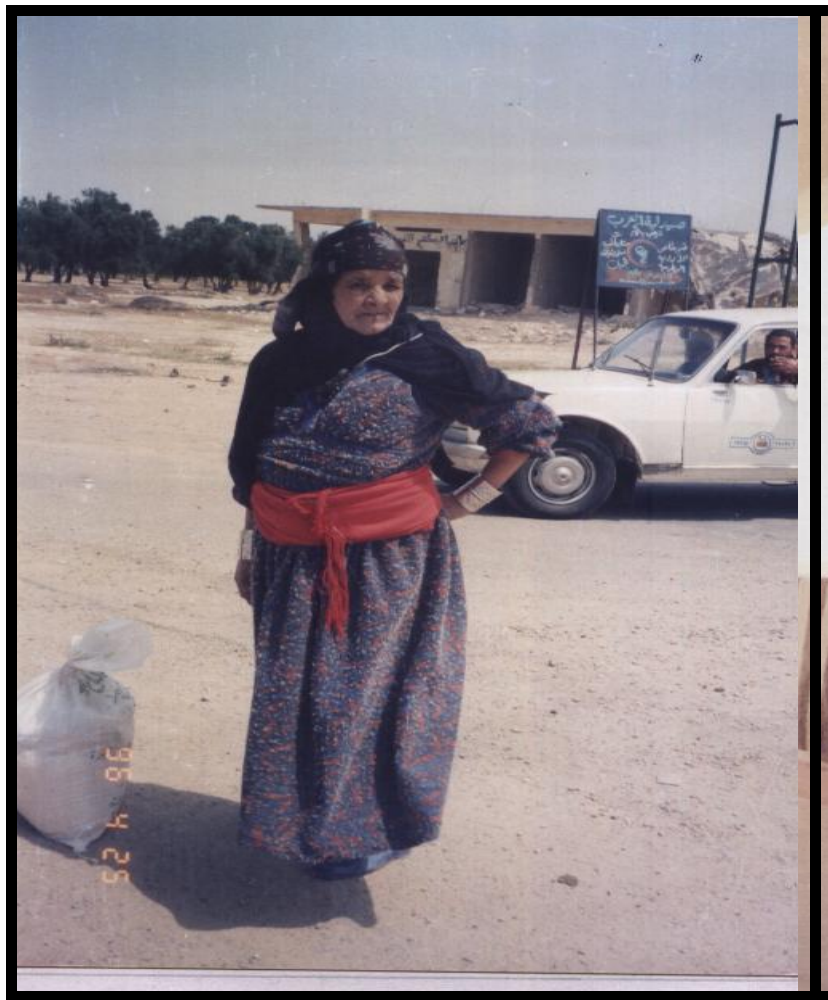

صوره رقمץ. سيده مسنه ترتدى الثوب بألوان زاهيه مع الخزم وفى يدها الدملج الفضه

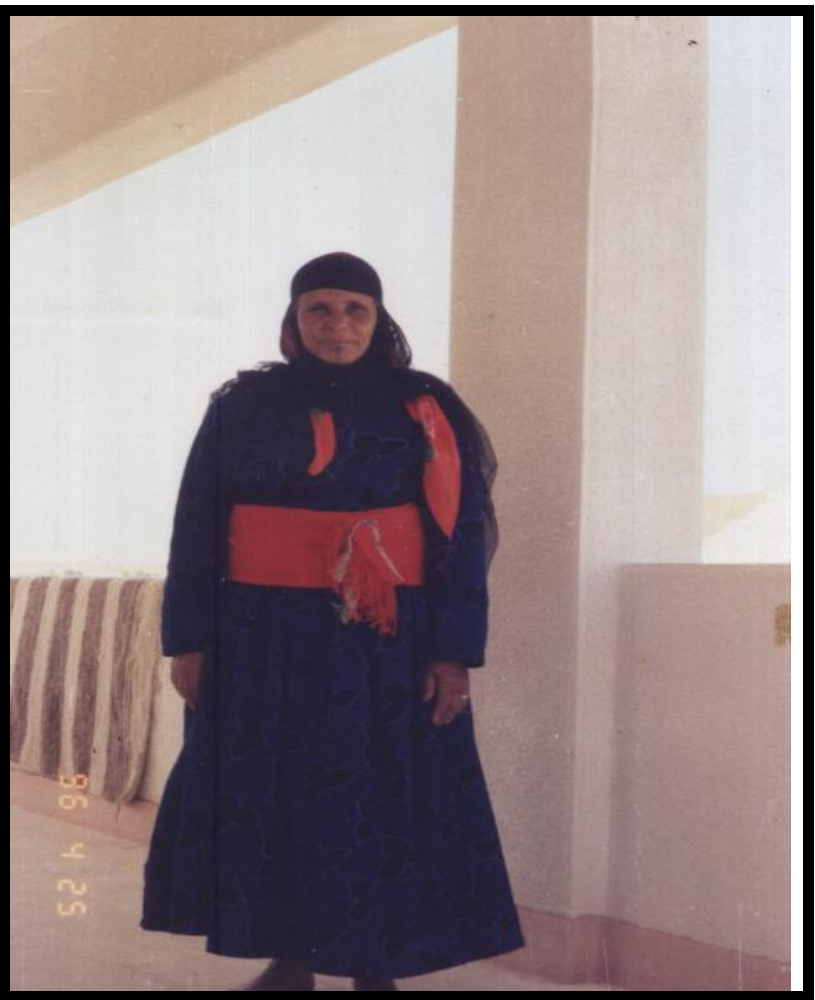

صوره رقم 1 ـ سيده ترتدى الجلباب مع الخزم وغطاء الرأس عبارة عن طرحه سوداء 


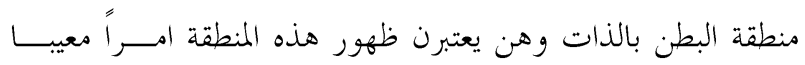
السروال الطويل كذلك يساعد الحزام على تثبيت الجلباب على خصر السيدة فيمنع

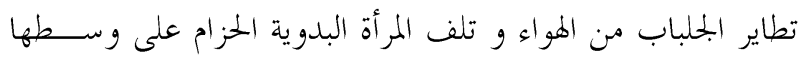

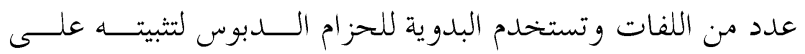
وسطها صور رقم (ب)، (ع) (كن) وهناك شكل آخر من الأحزمة وهويصنع من الأقمشة القطنيــة

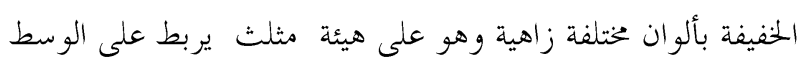

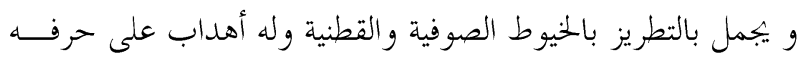

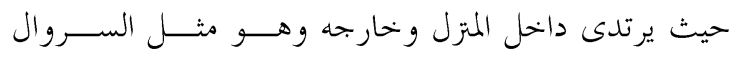

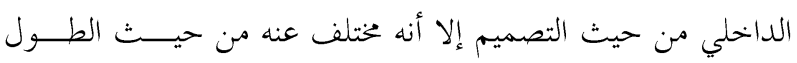

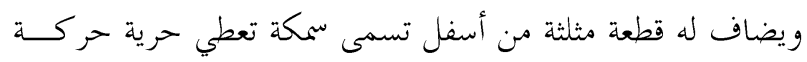

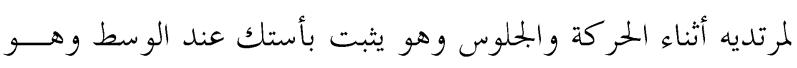

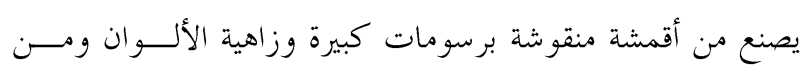

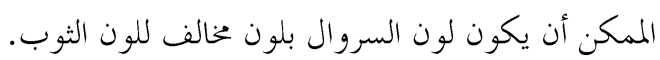

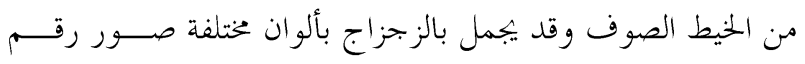

(7) (10)

ترتدى السيدة البدويه حزاماً فوق جلبابا و ينتشر ارتدائه واهم

وظيفة وتعتبر اخلاقية حيث اهم يرون ان الحزام يساعد على اخففاء
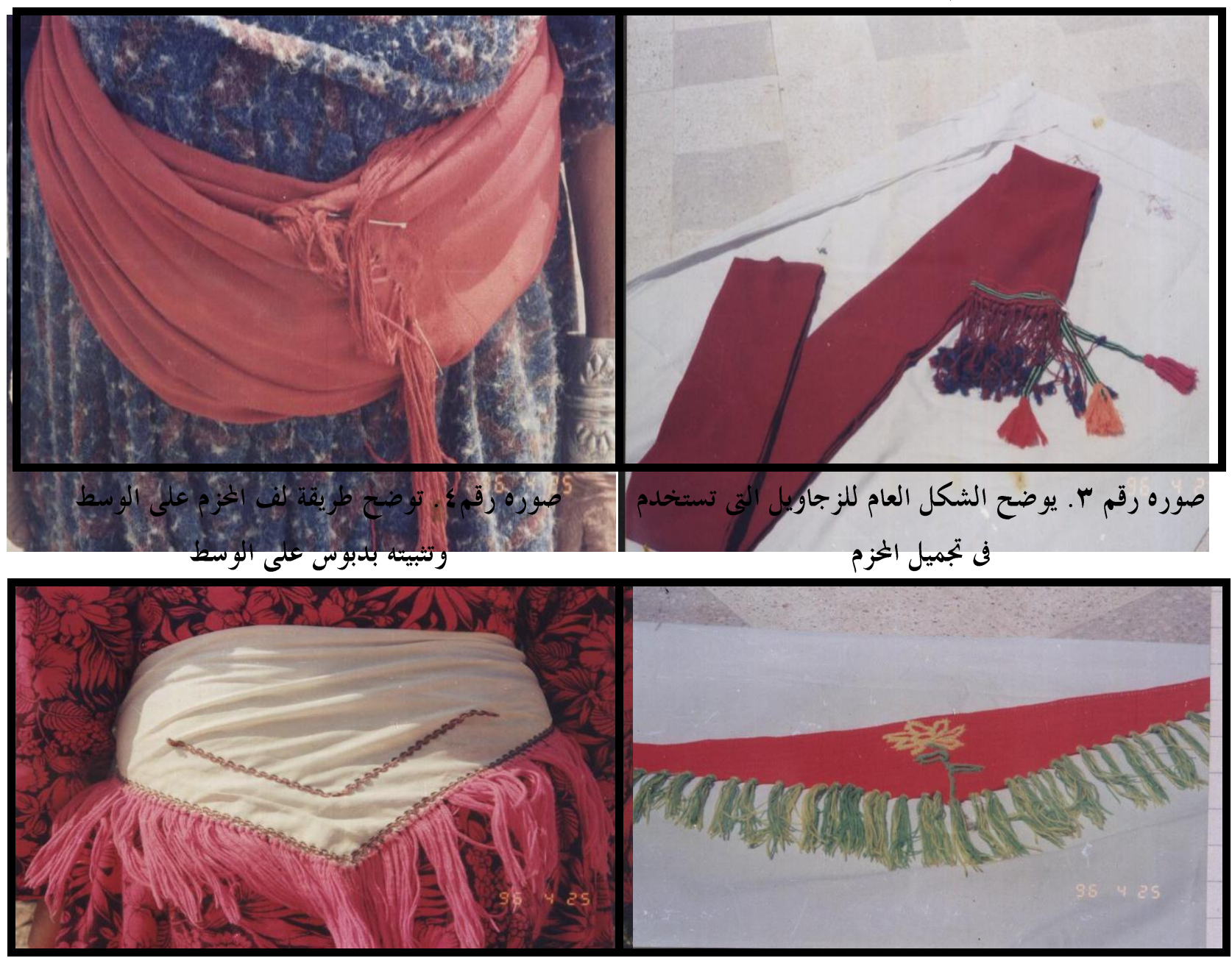

صوره رقم 7 . يوضح شكل من الأحزمه يجمل بالزجزاج والخيوط الصوفيه

$$
\text { والخيوط الصوفيه }
$$


ترتدي المسنات الشال الأسود فوق رؤسهن بحيث يوضع على

الطرحة

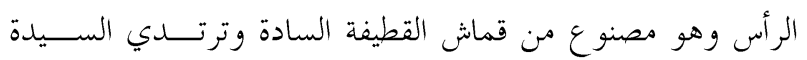

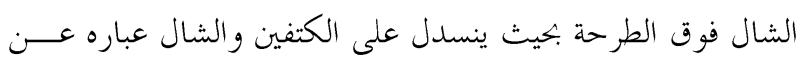

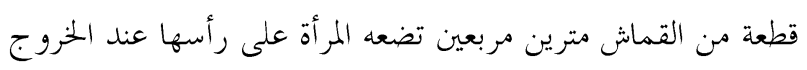

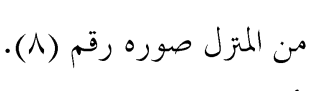

ألبسة القدم للنساء:

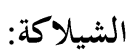

وهي حذاء بوط يصنع من جلد الماعز ويطرز بخيوط حريريسـة

بألو ان زاهية وهي غالية الثمن.

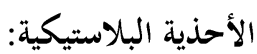

وهي أحذية خفيفة الوزن رخيصة الثمن تصنع من البلاستيك البك الهن

والطرحة بمعنى غطاء يطرح على الرأس والكتفين و الصدر(عبد

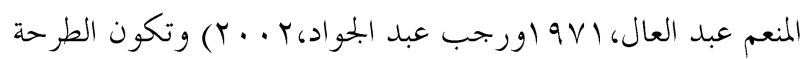

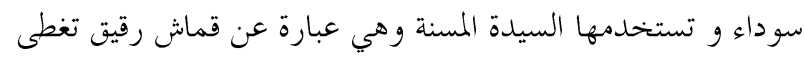

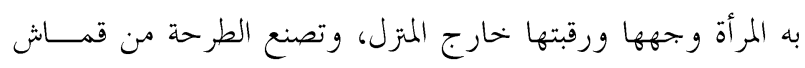

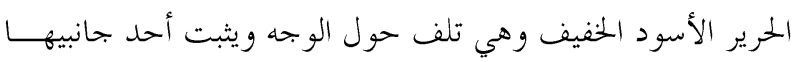
ويترك باقي الطول منسدلاً وقد يؤخذ باقي الطول المنسدل ليغطيـي

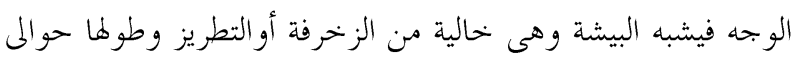

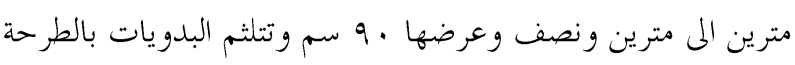
داخل المسكن وذلك عند وجود أحد الغرباء صوره رقم (V)، (N).

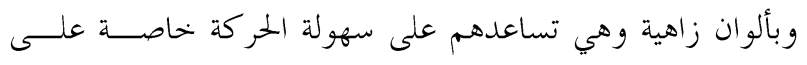

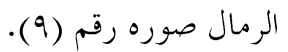

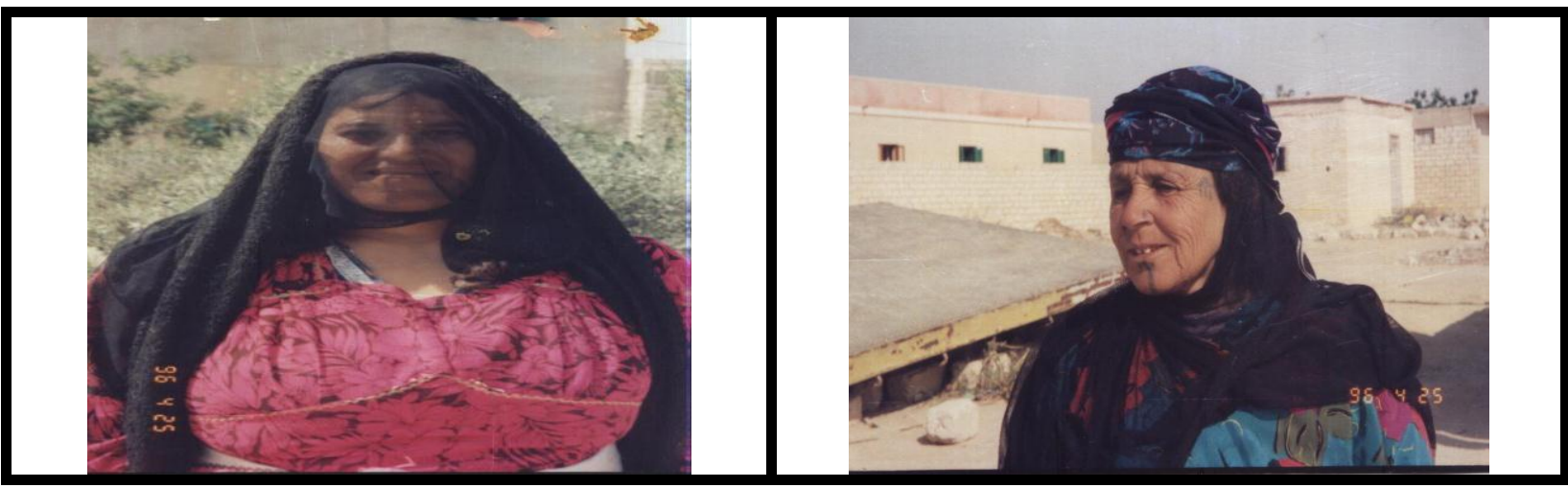

صوره رقم ^. سيدة ترتدى الجلباب الثوب بقصة فى

صوره رقم V . توضح سيدة بدوية ترتدى طرحه سواداء

الصدر و بألوان زاهية وتغطى وجهها بطرحة سوداء

وعلى ذقنها وشم يسمى حرقوس و بجانب عينها وشم

وعلى رأسها شال أسود

أخر الممه تجريح

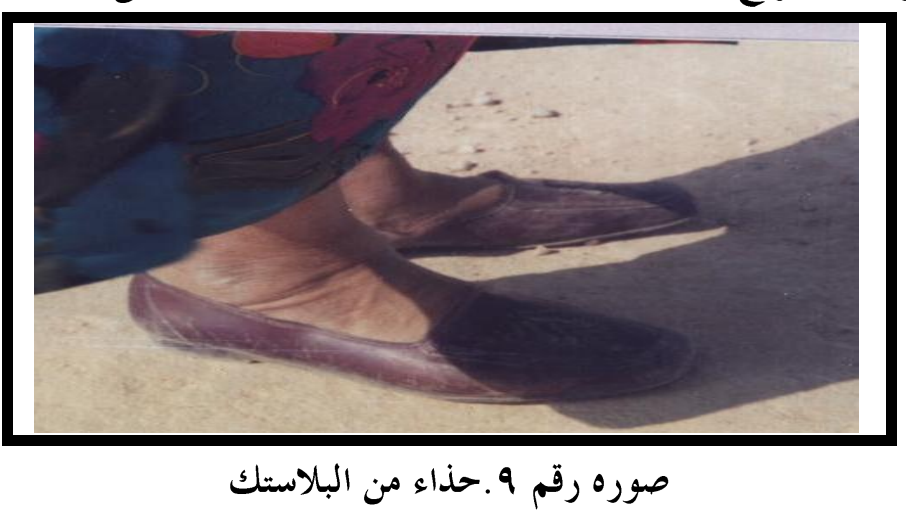


ويرتديه الرجال فوق الجلباب صيفاً وشتاءًا وهو عبارة عـنـ

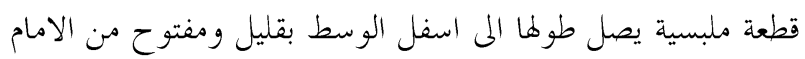

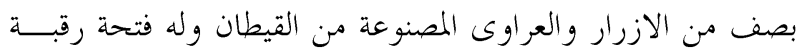

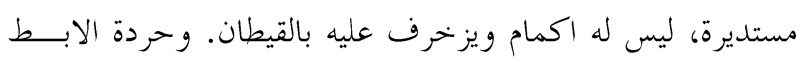
تتميز باتساع لتسهيل حركة الزراعين لارتدائه فوق الجلباب صوره

رقم (r) (I).

$$
\text { الجرد }
$$

ينسج من الصوف الطبيعى الابيض المائل للاصفرار علـى شـــكل

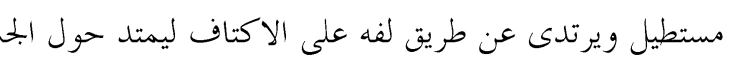
ويتم ارتدائه بمسك أحد اطر اف عرض طرض القماث لفه على الى الكتف الايسر لينسدل هذا الطرف على الصدر لاسفل تم يمرر طول القماش مــن

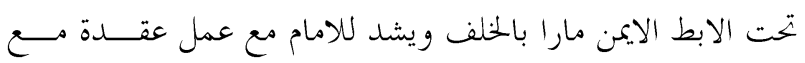

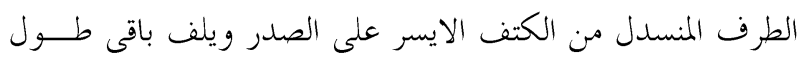
القماث حول الجسم ويوضع على الكتف الايمن ويترك منسدلاً على الجسم صوره رقم (1 (I)، (ع (I).
ب- - دراسه لملابس الرجال بمنطقة البحث

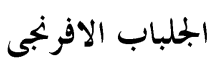

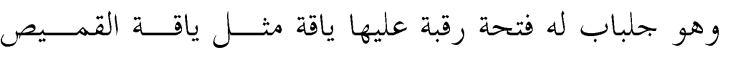
الافرنجى و له فتحة امامية عليها مرد يصل الى اعلى الوسط قلمسيلاً

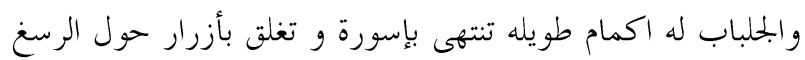

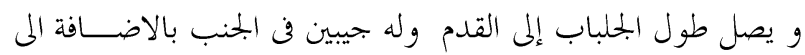
جيب صغير على الصدر من اليسار منه لون ابيض او ابيض مائـلـل للاصفر ار صوره رقم (·) (1). جلباب الاصيل عبارة عن رداء طويل يصل طوله الى القدم و بفتحة رقبة عليها

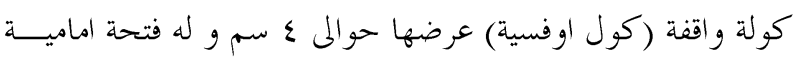

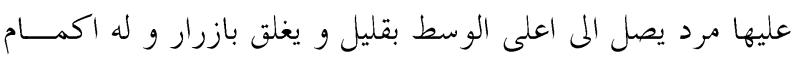

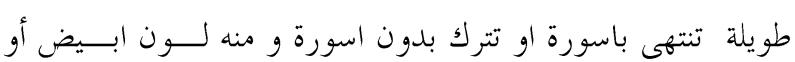
ابيض مائل للاصفرار صوره رقم (1) (1). الصديرى

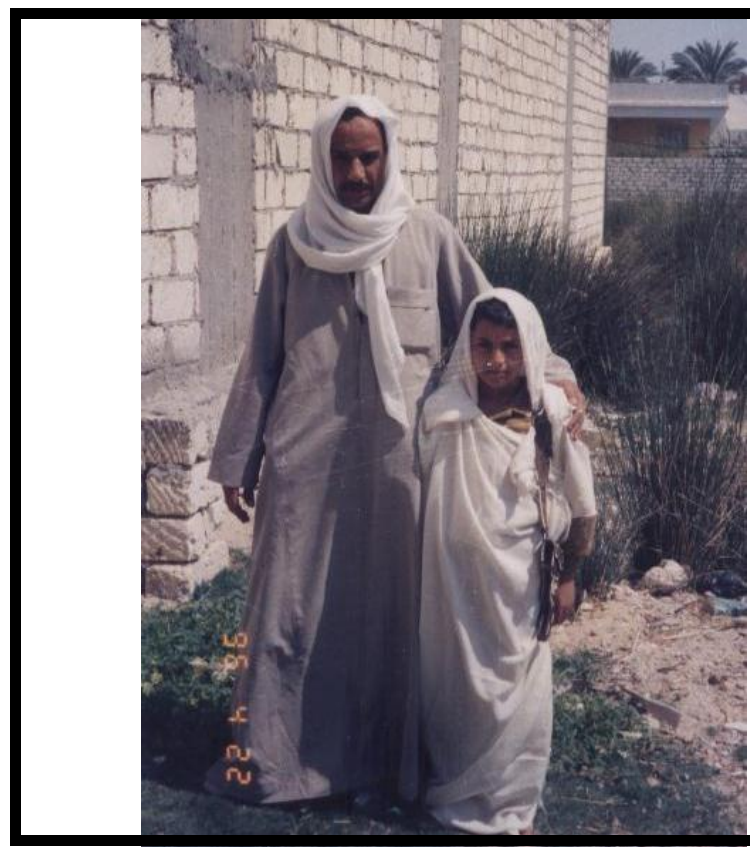

صوره رقم 1 ــرجل يرتدى الجلباب الأصيل وطفل يرتدى

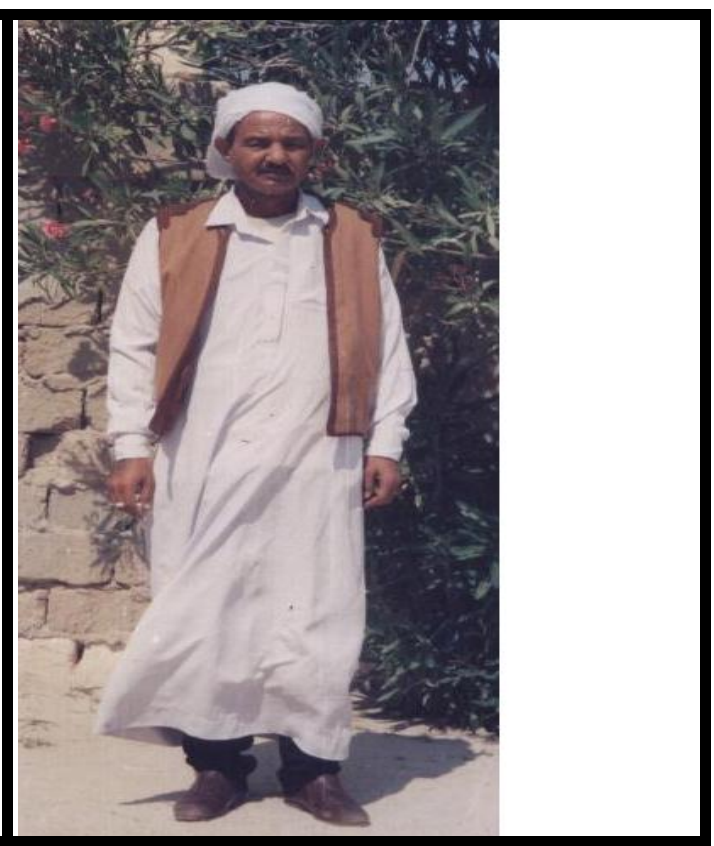

صوره رقم • 1 ـالجلباب الافرنجى مع الصديرى 

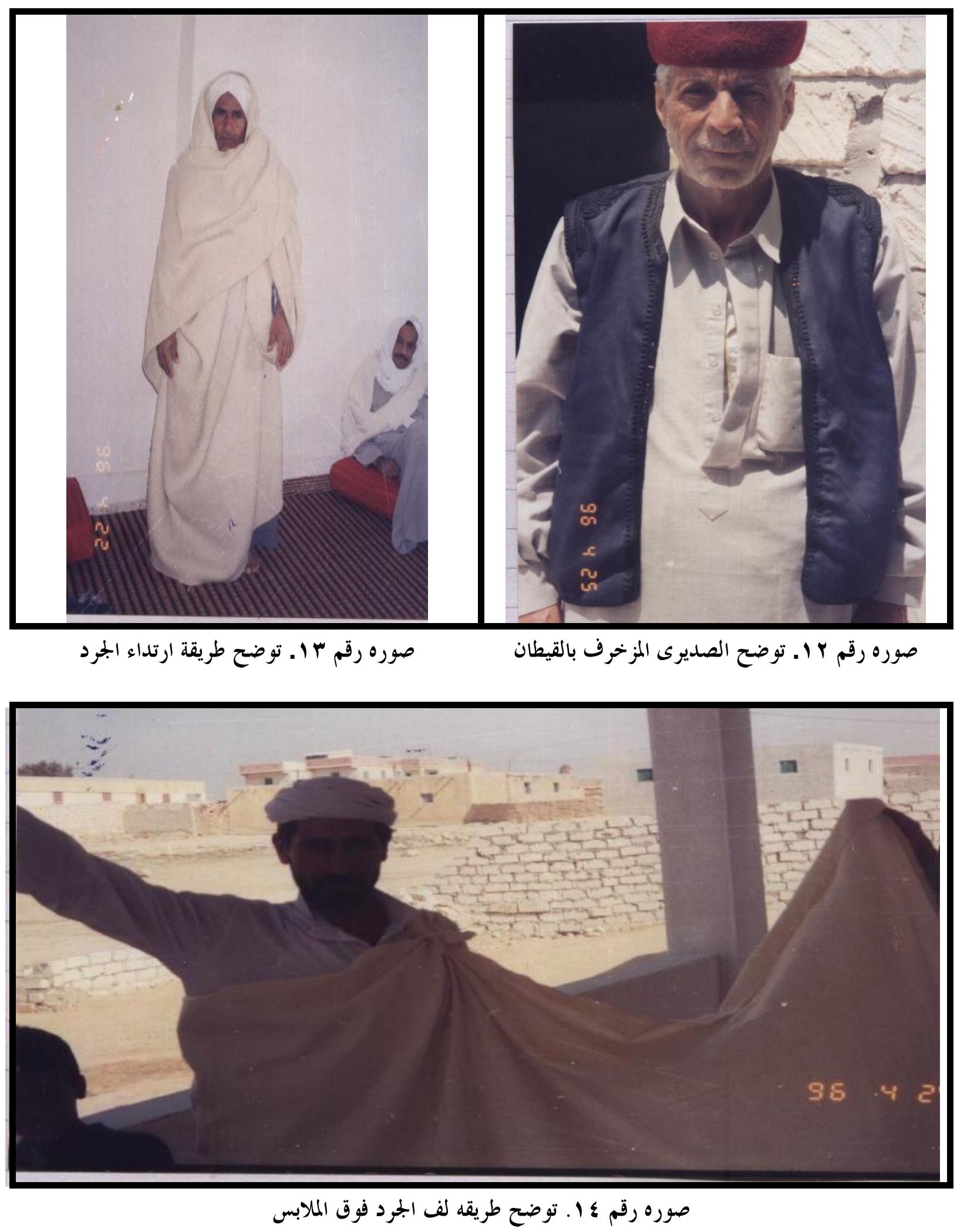
الصمادة:

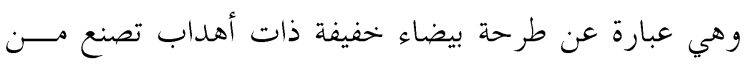

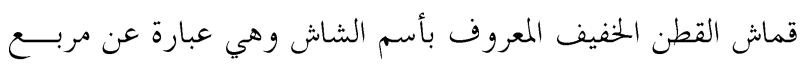
يطوى على هيئة مثلث ليوضع على الرأس يصل طول ضلعه حوالي

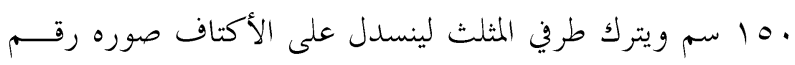

ألبسة القدم: الشيلاكة:

لباس القدم للرجال وهو حذاء مثل البوط لونه بين مفتوح من

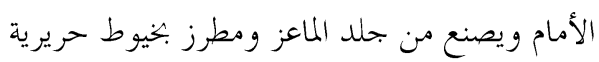
الأحذية الجلدية: - الأمام ويصن

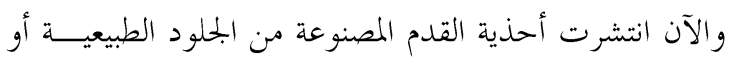
الصناعية والتي يرتديها باقي أفراد البحتمع.

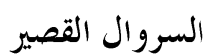

ويصل طوله من الوسط حتى اسفل الركبة ويثبت بواسطة شريط من الحبال عند الوسط ويكون باتساع كافى ليعطى راحة لمرتديه اثنــاء

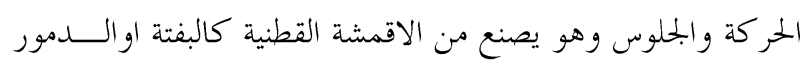

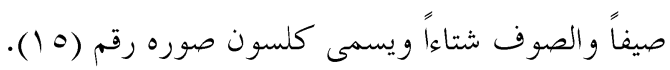

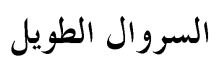

ويرتدى السروال الطويل فوق السروال القصــير ويسـتـخدم

داخل المتزل وخارجهه ويصنع من الاقمشة القطنية كالبفتة اوالدمور صيفاً والصوف شتاءًا ويزخرف آلمرل ونليه بالقيطان.

$$
\text { أغطية الر أس للرجال }
$$

الشنة:

وهي مصنوعة من الجوخ الأحمر ويرتديها المسنين وهي دليـل

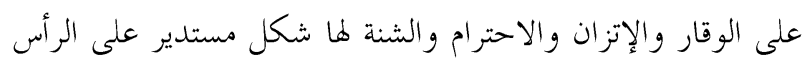

صوره رقم (1 (1). (1) - (1)

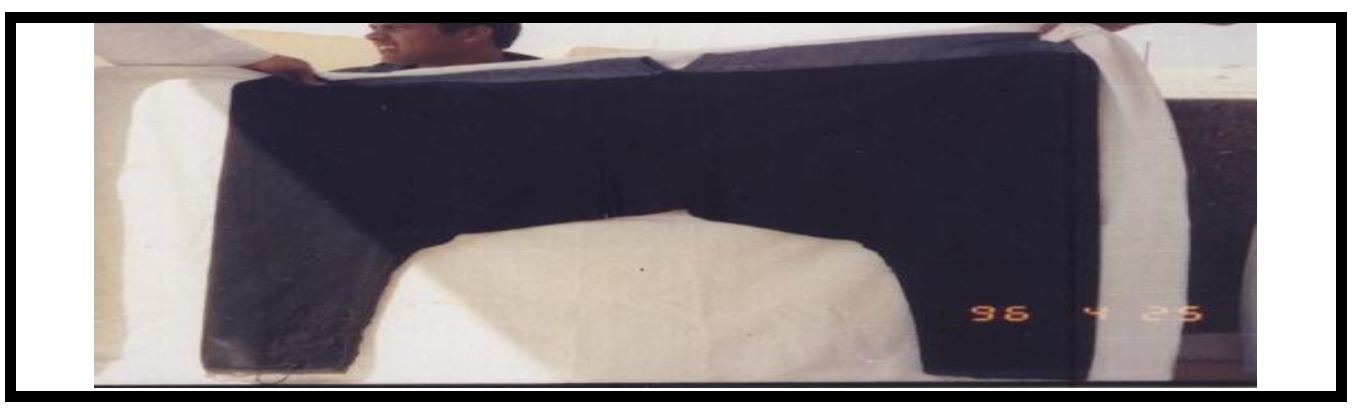

صوره رقم 1 ـ السروال القصير

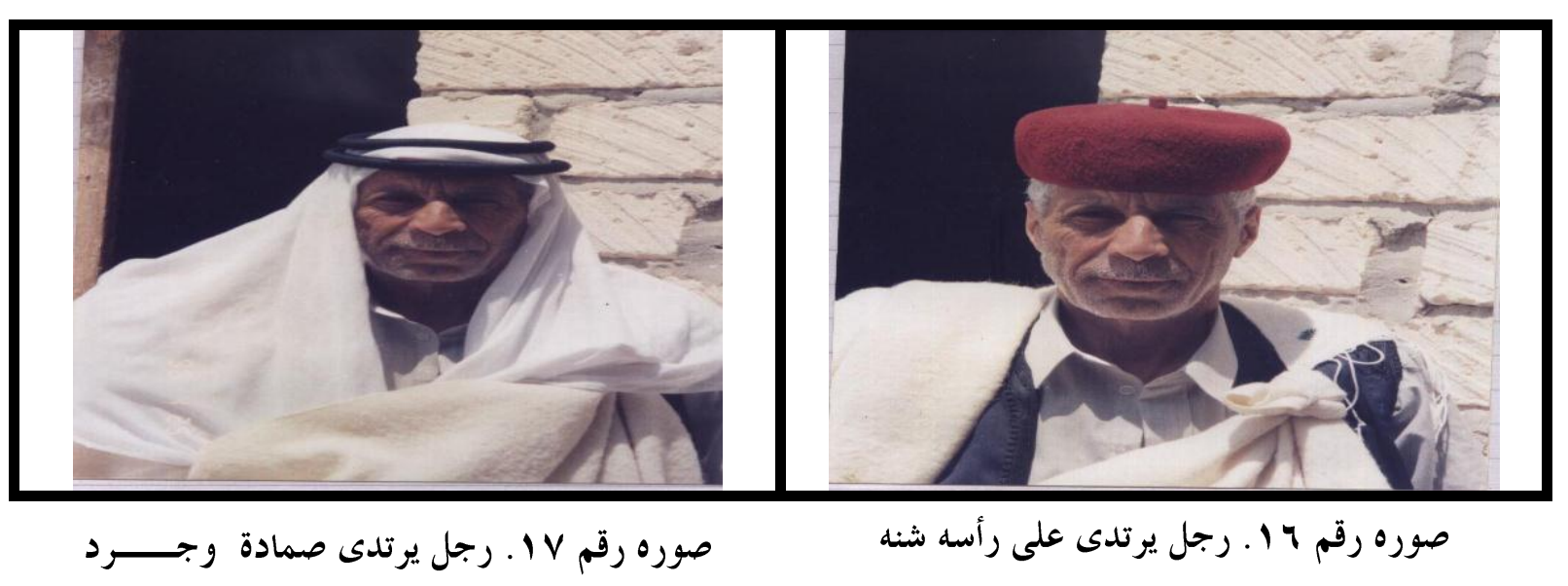


الكردان

وهى قلادة ترتدى حول الرقبة وتتدلى على الصدر وهو مــنـ

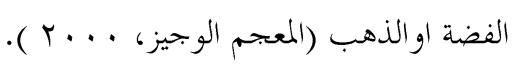

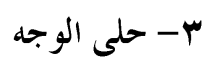

الشناف

تستخدم البدويات الشناف لتزيين الوجه و يكون الشـــاف

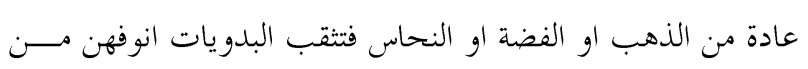

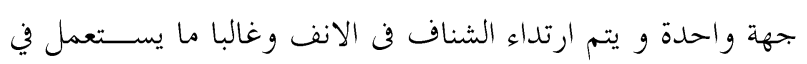

$$
\text { الجهة اليمني. }
$$

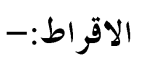

وهى ترتدى في الأذن وتتحذ شكل الهلال وتصنع من الذهب

$$
\text { الذواجة الفضة صورة رقم (·r). }
$$

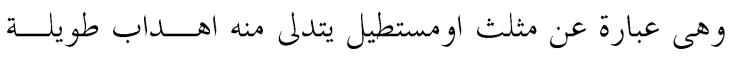

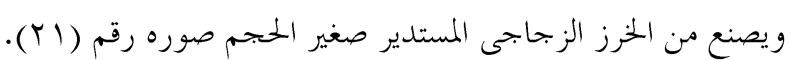

ثانيا:- الدراسه التحليليه لمكملات الزى بمنطقة البحث

$$
\text { ا- - حلى الاطراف }
$$

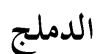

هو سوار يحيط بالعضد او المعصم (المعجم الوســيط، ... ب)

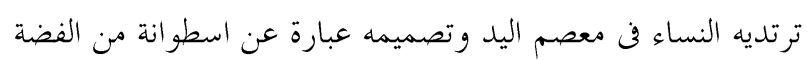

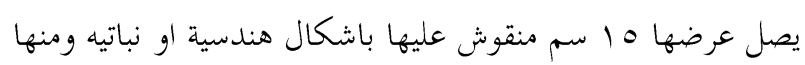
انواع بدون زخارف والدملج له فتحة طويلة حتى تتمكن الســيدة من ارتدائه حول معصمها وهى حلية من الذهب مستديرة كالحلقة

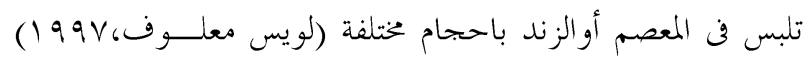

شكل (11) (19)، (1).

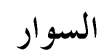

هى حلقة متصلة من الفضة او الذهب بعرض ع سم وهو غير

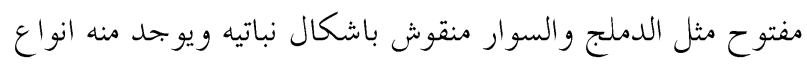

بدون نقوش (لويس معلوف، 99 1 (1). r- ب - بلى العنق والصدر

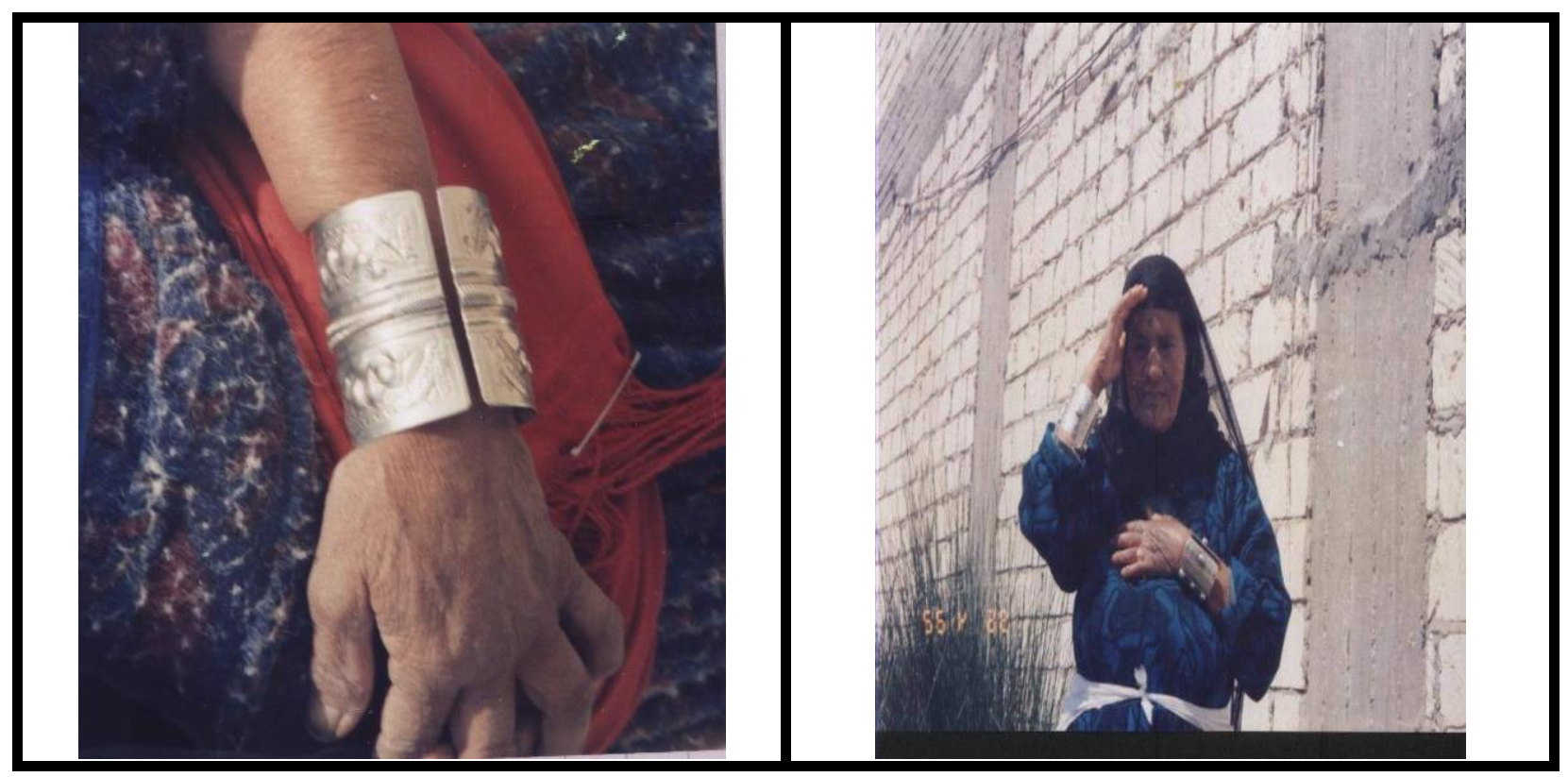

صوره رقم 9 1. دملج فضة للسيدات كبار السن

صوره رقم 1 1 ـ سيدة مسنه ترتدى الثوب الأسود و في

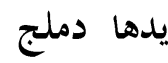




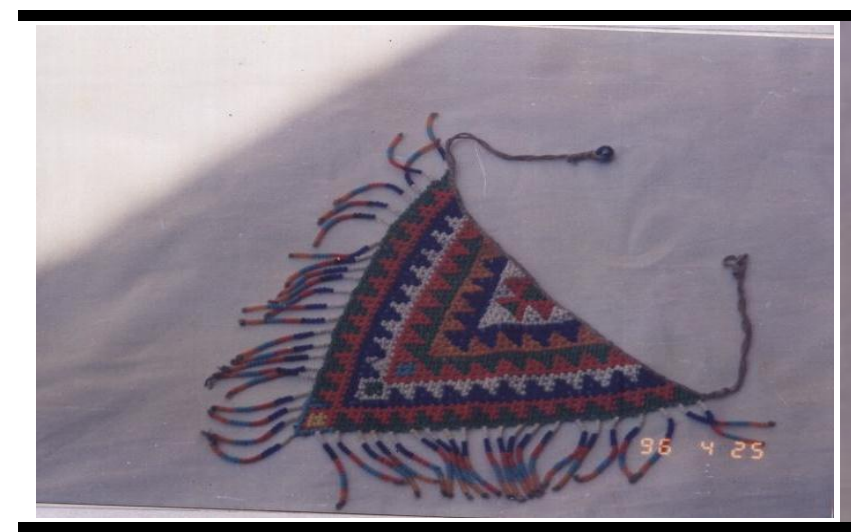

صوره رقم ا ب. الذراجة

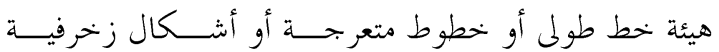

$$
\text { أخرى. }
$$

الثالث: الوشم على وجه البدوى علامة على أنه بدوى فيعرفه غيره

$$
\text { من القبائل ويسهل مناصرته. }
$$

التكحيل

استخدم النساء الكحل من قديع الزمان لجمال العين وهم يعتقــــون

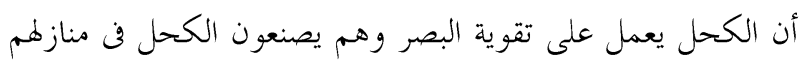

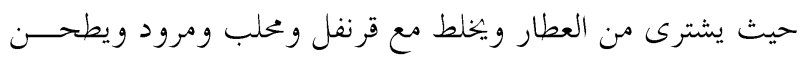

$$
\begin{aligned}
& \text { ناعم ثم يتم خلطه بزيت الزيتون. } \\
& \text { كيس المكحلة }
\end{aligned}
$$

تصنعه البدوية من الخرز الملون الزجاجى المستدير صغير الحجم و الترتر وتتدلى منه أهداب طويلة وهو يعلق بجانب المرآة على الحائط

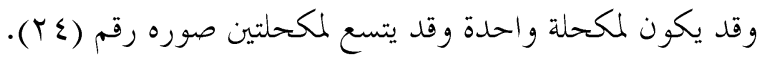

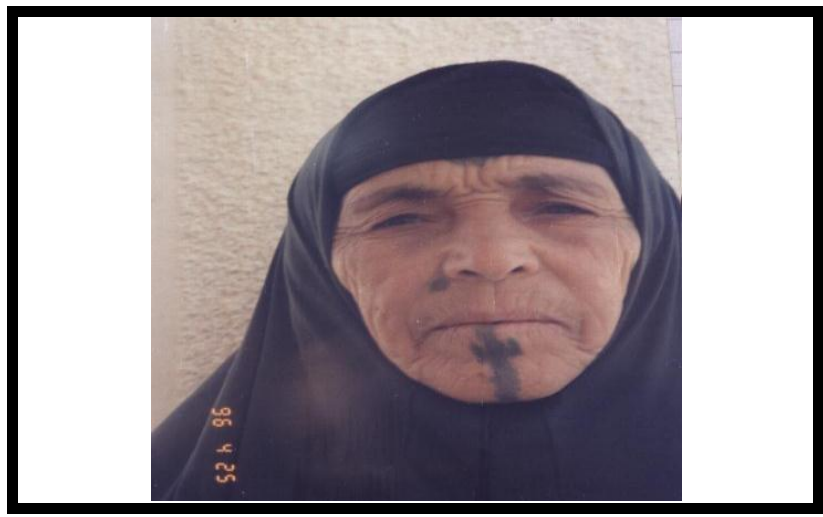

صوره رقم بr. . وشم على وجه سيده

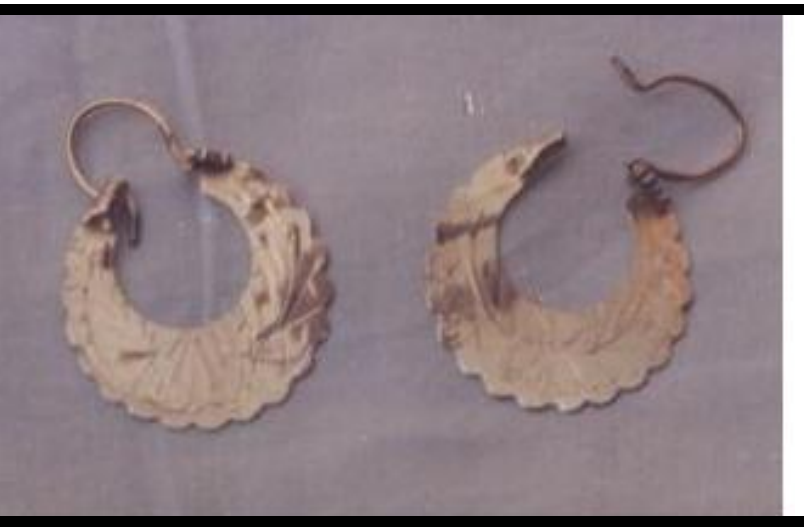

صوره رقم •r. - الأقراط

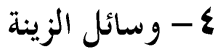

الوشم

وهى إحدى طرق التزيين عند المرأة وتتم بوخز الجلد بمجموعة

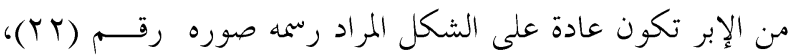

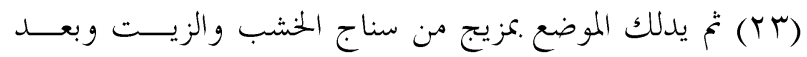

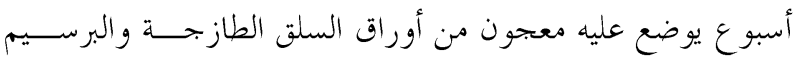
فيكسبه لون أزرق مخضر ( سليمان محمود، ه و 1 ). ويستخدم لثلاثة أغراض:الأول: كدواء لبعض العلل فهناك عروق في الجسم يدقون عليهـــا

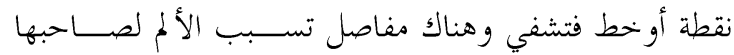
ويكون الدواء الدق عليها بالإبرة

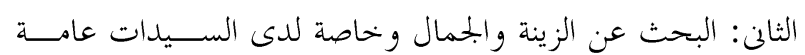
ومناطق الدق ( الوشم ) للزينة لدى السيدات هى الذقن على ترلى

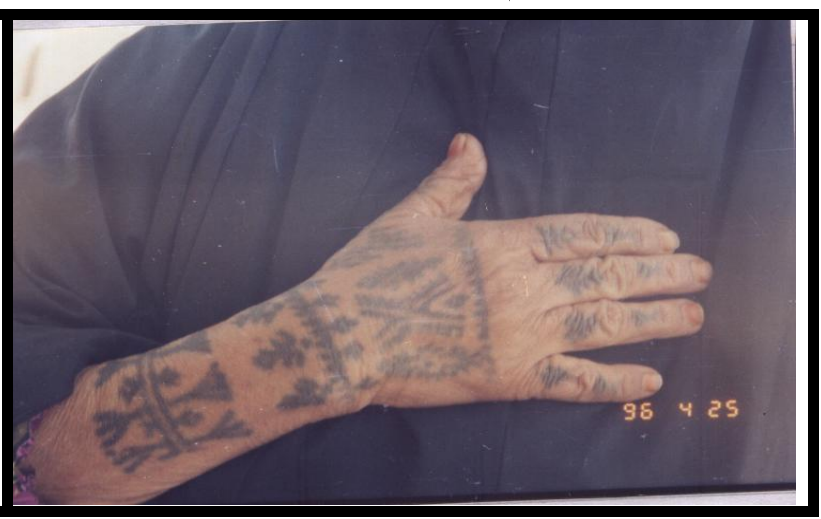

صوره رقم Y r . . وشم يسمى ورق الزيتون ثم المقص ثم كوم النخل 


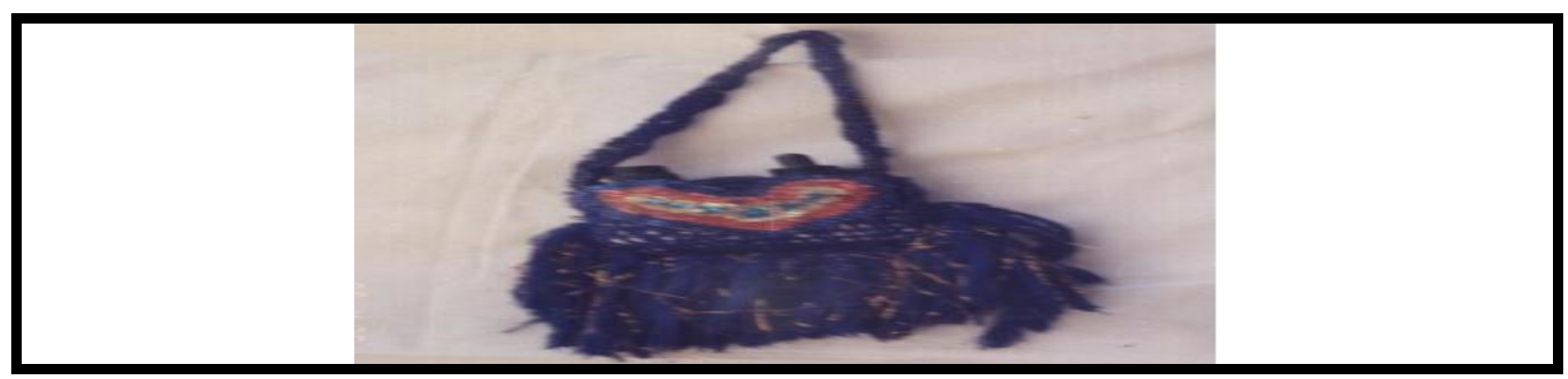

صوره رقم ع Y.كيس مكحلة مطرزة بالحرز والترتر بألوان زاهية

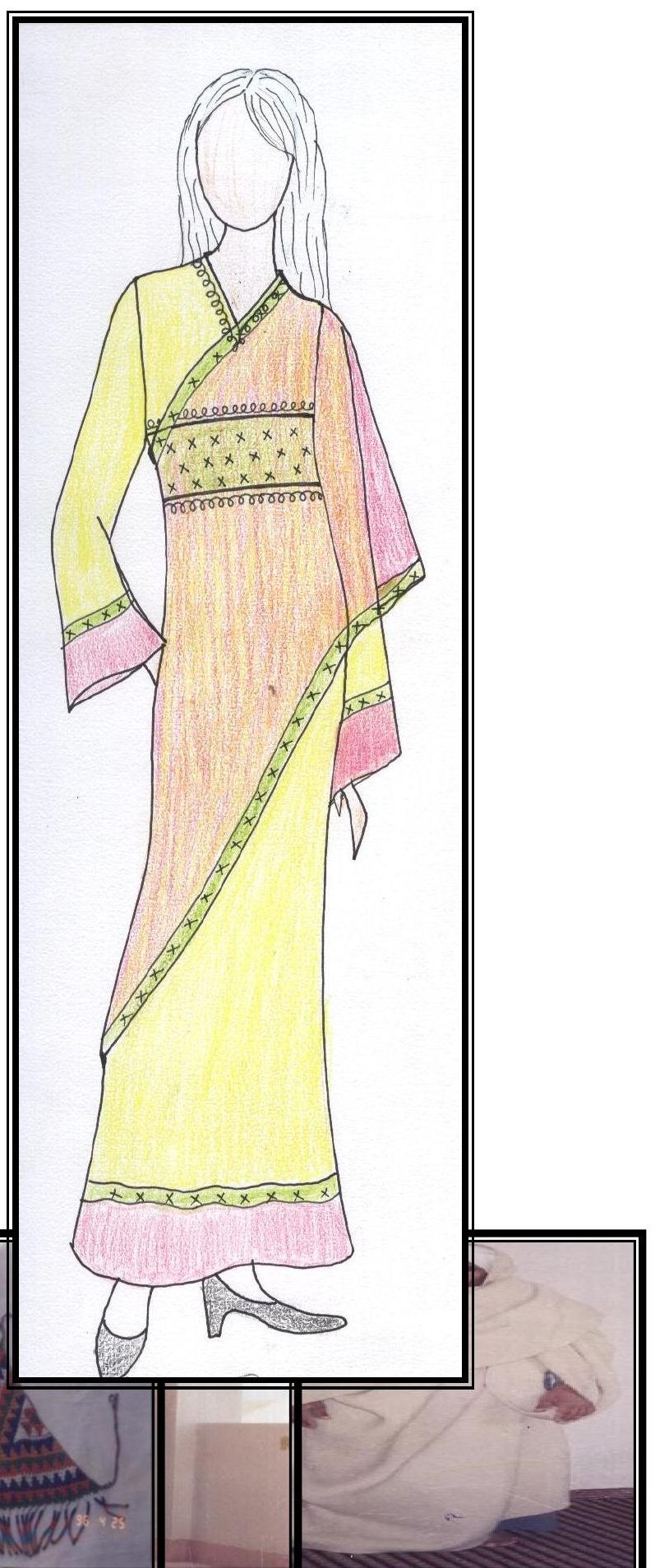

ثالثا الاستفاده من الأزياء بمنطقة البحث لتصميم ملابس معاصره

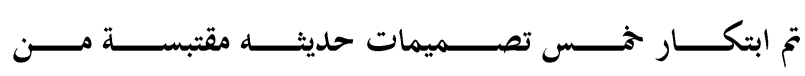

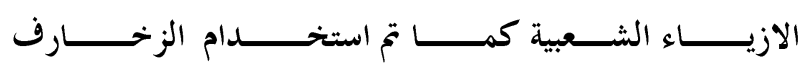

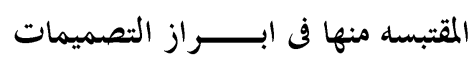
التصميم الأول التصميم البنائى: يتكون مــن قطعـتين الســفلية عبــارة عــن

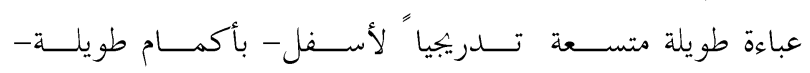

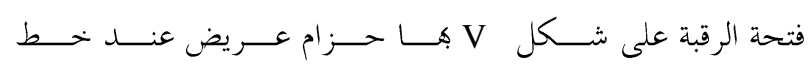

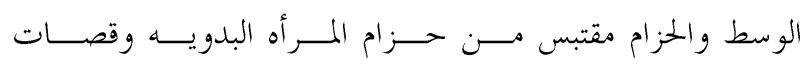

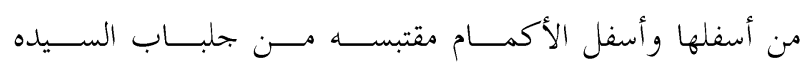
البدويه.

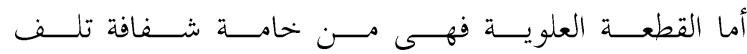
حول الجسم باتحاه الورب مستوحاه من الجرده.

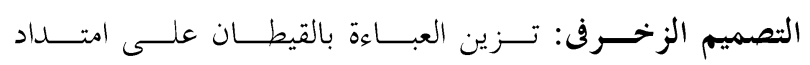

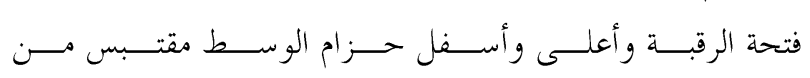

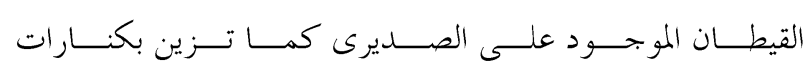

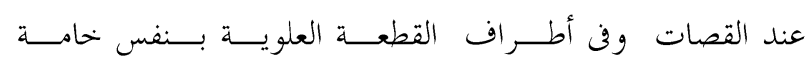

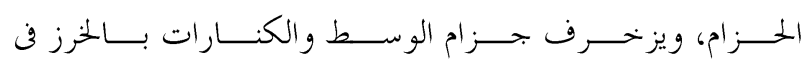
شكل وحدة زخرفية مستلهمة من الوشم.

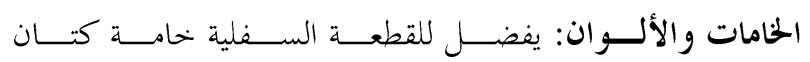

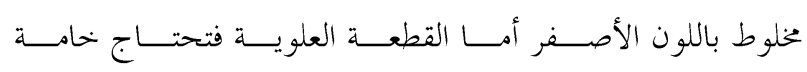

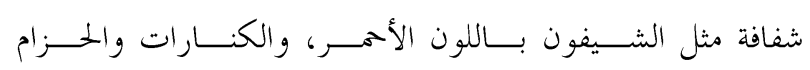

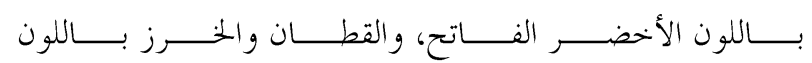

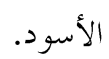



مصدر الأقتباس
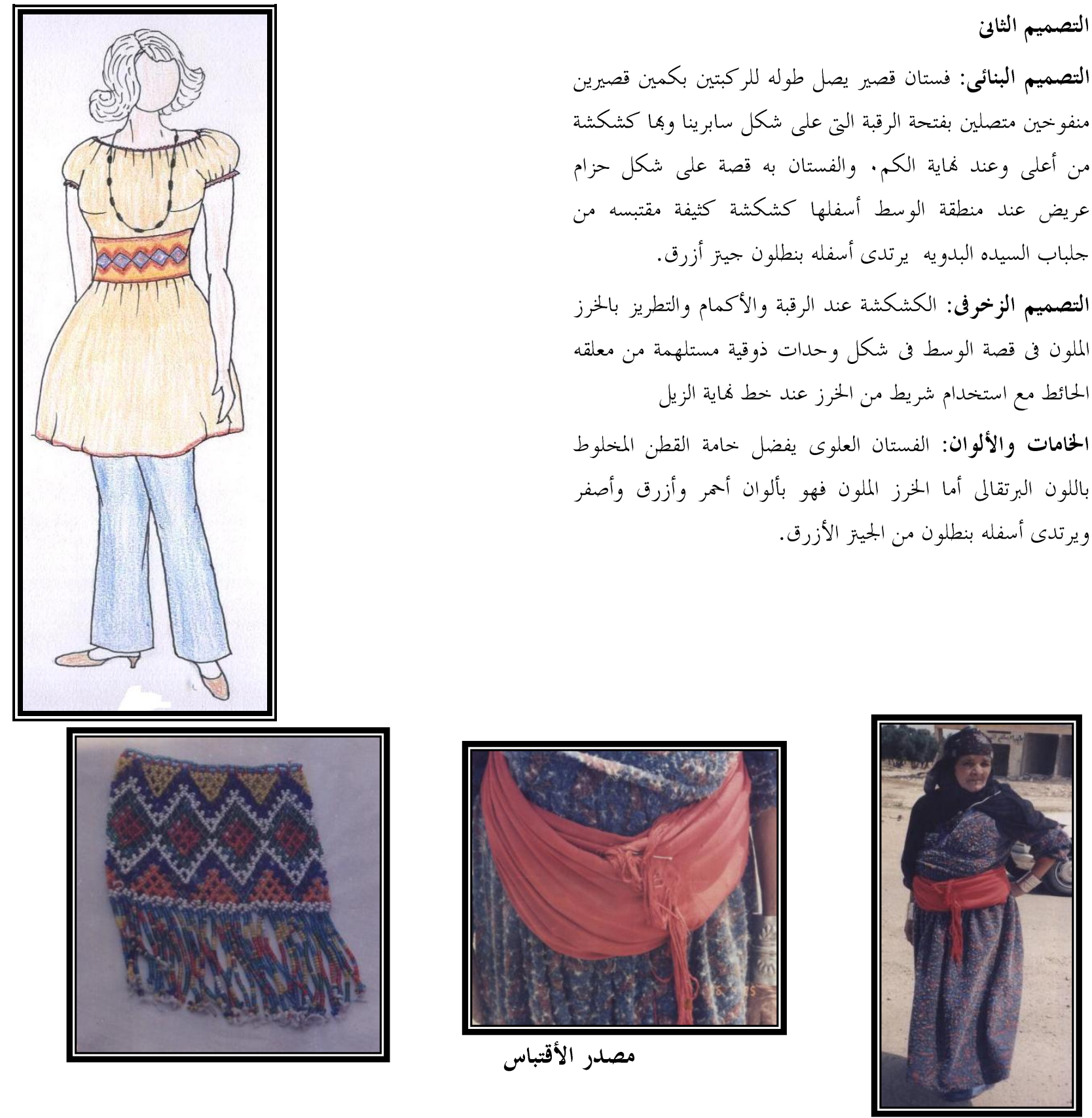



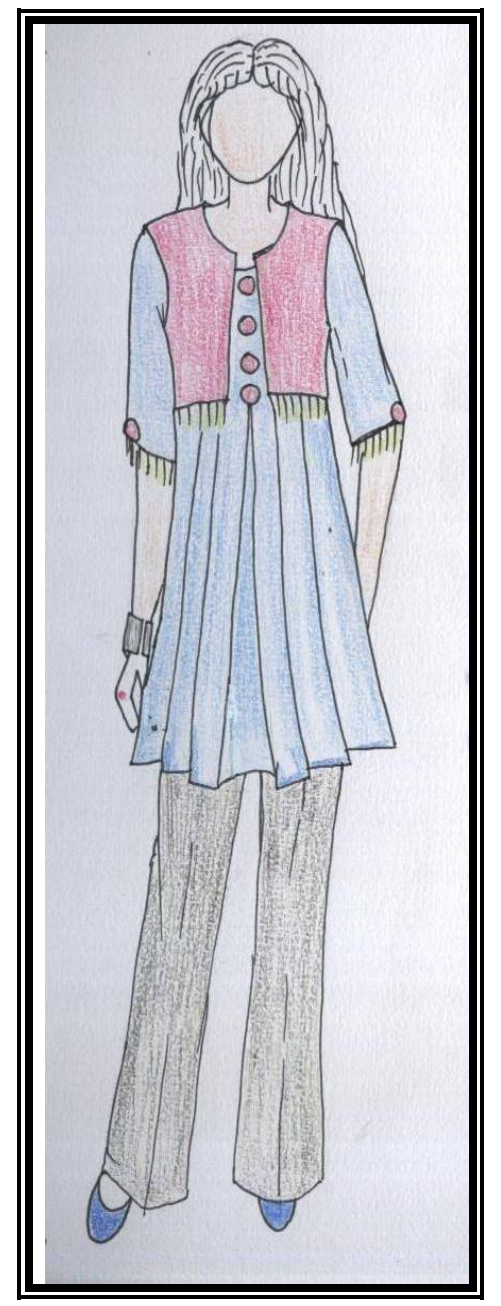

$$
\begin{aligned}
& \text { التصميم الثالث } \\
& \text { التصميم البنائى: مكون من قطعتين: }
\end{aligned}
$$

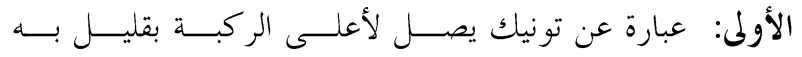

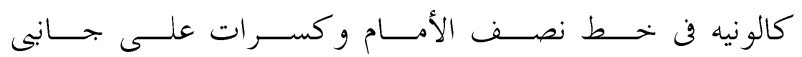

$$
\begin{aligned}
& \text { الكالونيه وبأكمام قصيرة تصل للكوع. فيك. }
\end{aligned}
$$

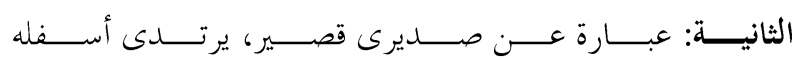

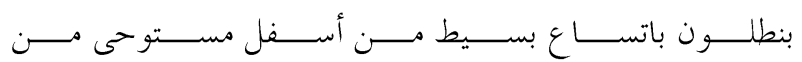

$$
\begin{aligned}
& \text { الصديرى. }
\end{aligned}
$$

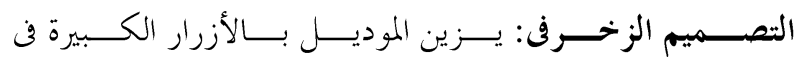

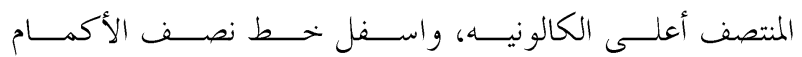

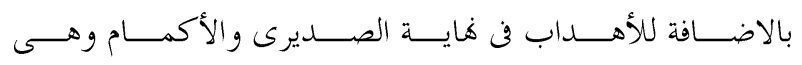

$$
\begin{aligned}
& \text { مستو حاه من المززم و الزراجه. }
\end{aligned}
$$

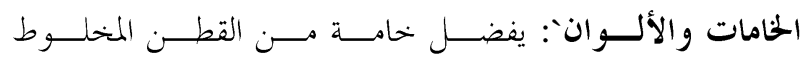

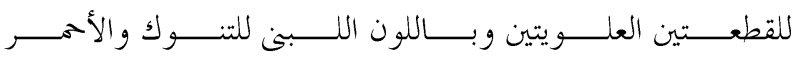

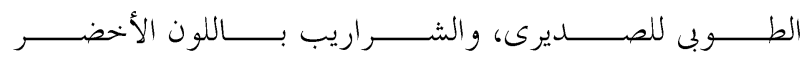

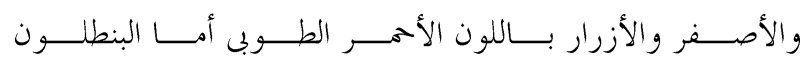

$$
\begin{aligned}
& \text { فهو من خامة صناعية سوداء. }
\end{aligned}
$$
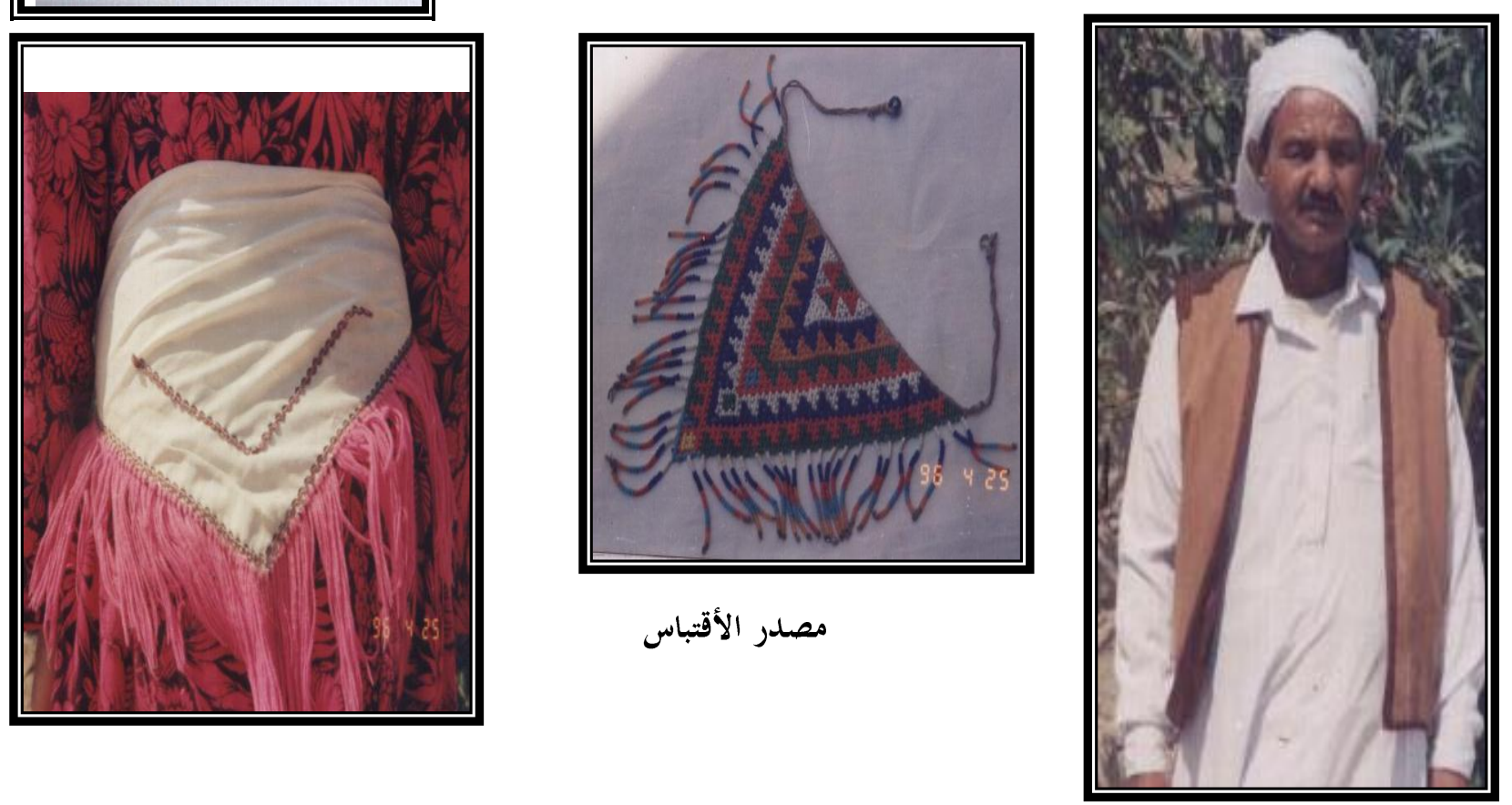


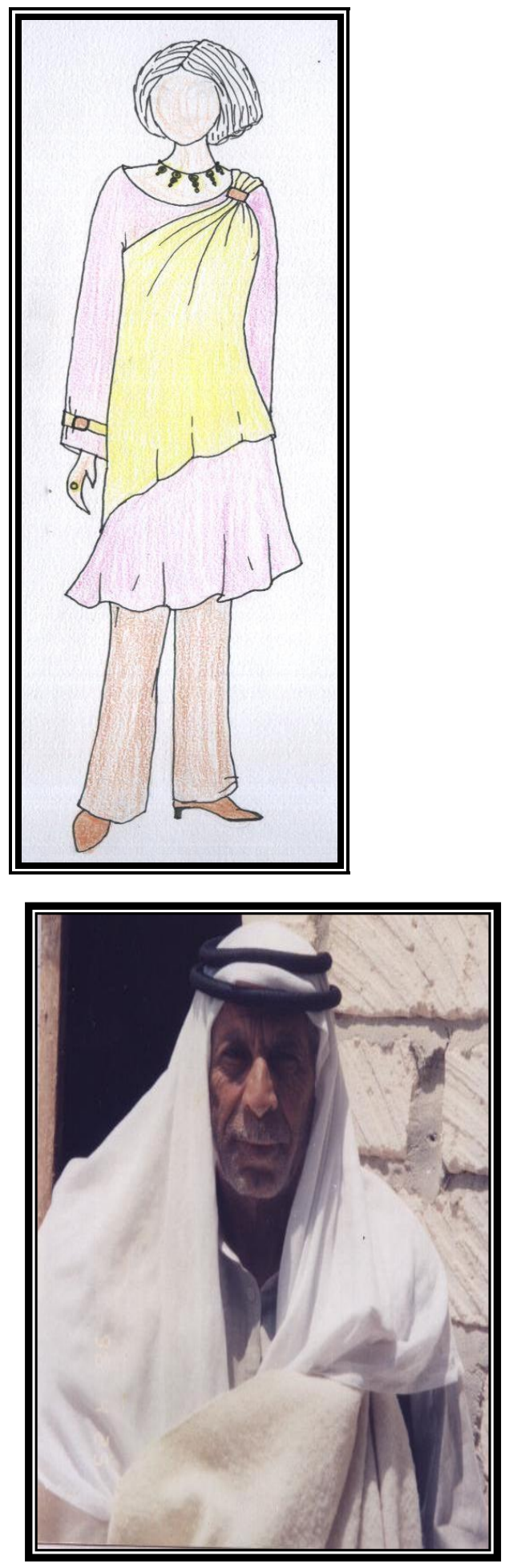

$$
\text { التصميم الرابع }
$$

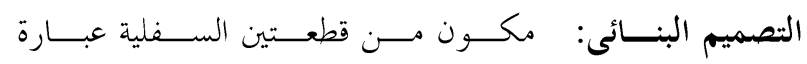

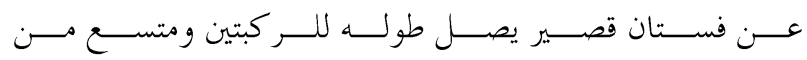

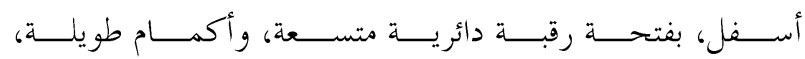

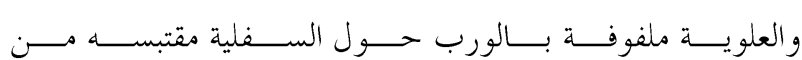

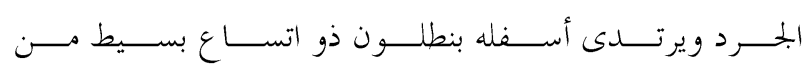

أسفل.

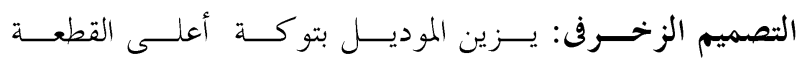

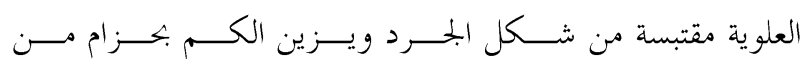

خامة القطعة العلوية وبه نفس التوكة.

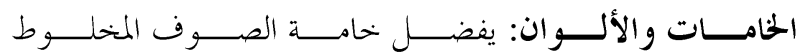

التريكو بــاللون البنفســـى للقطعــة الســفلية وقمــاش مــنـ

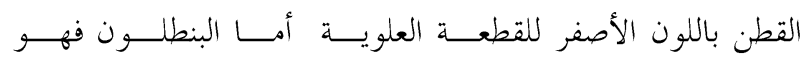

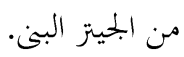

مصدر الأقتباس

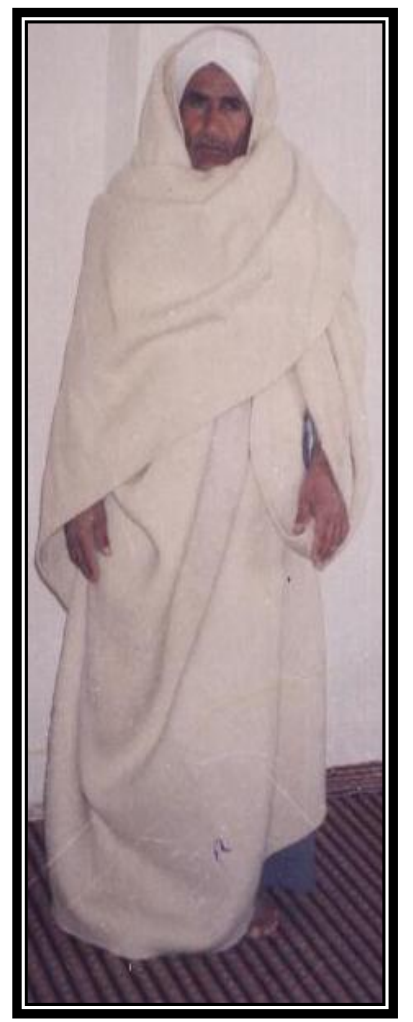





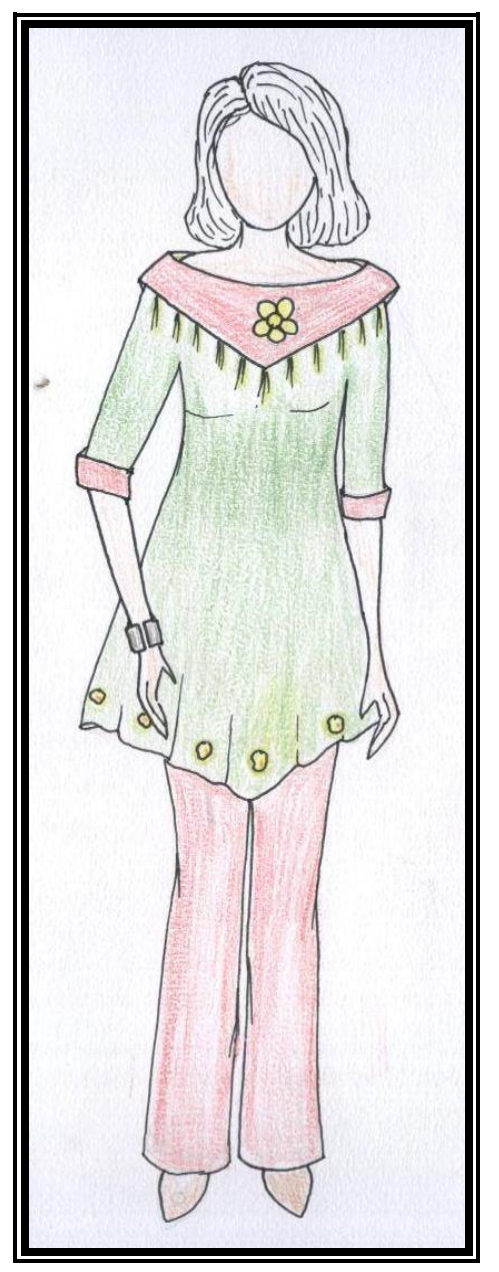

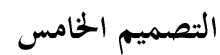

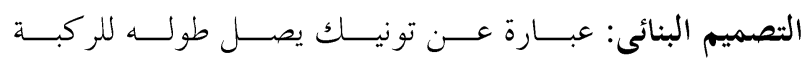

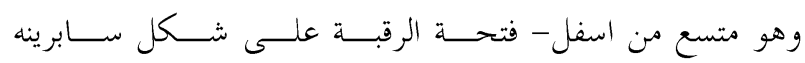

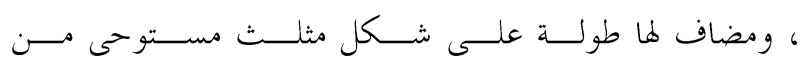

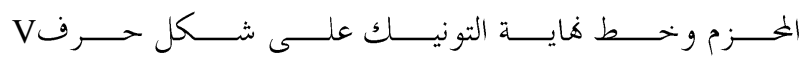

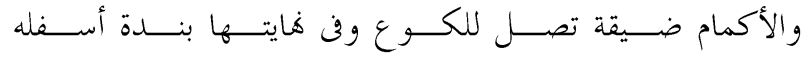

$$
\begin{aligned}
& \text { بنطلون به اتساع بسيط من اسفل. }
\end{aligned}
$$

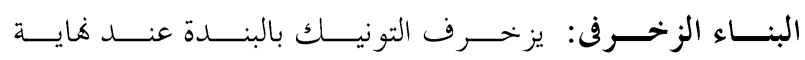

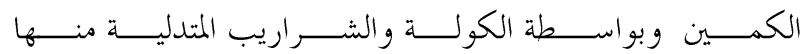

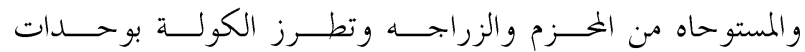

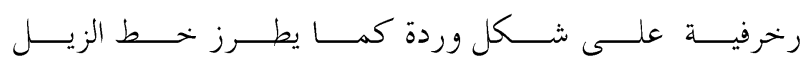

$$
\begin{aligned}
& \text { بوحدات زخرفية دائرية. }
\end{aligned}
$$

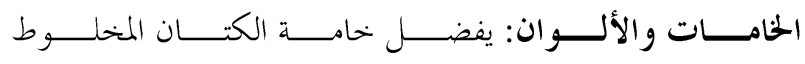

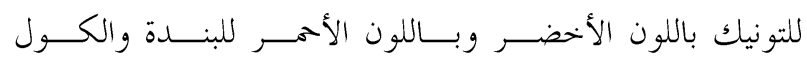

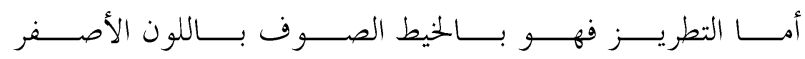

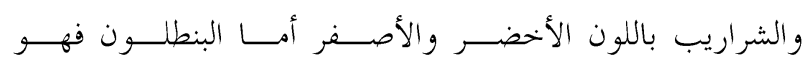

$$
\begin{aligned}
& \text { من نفس الخامة باللون الأحمر. }
\end{aligned}
$$
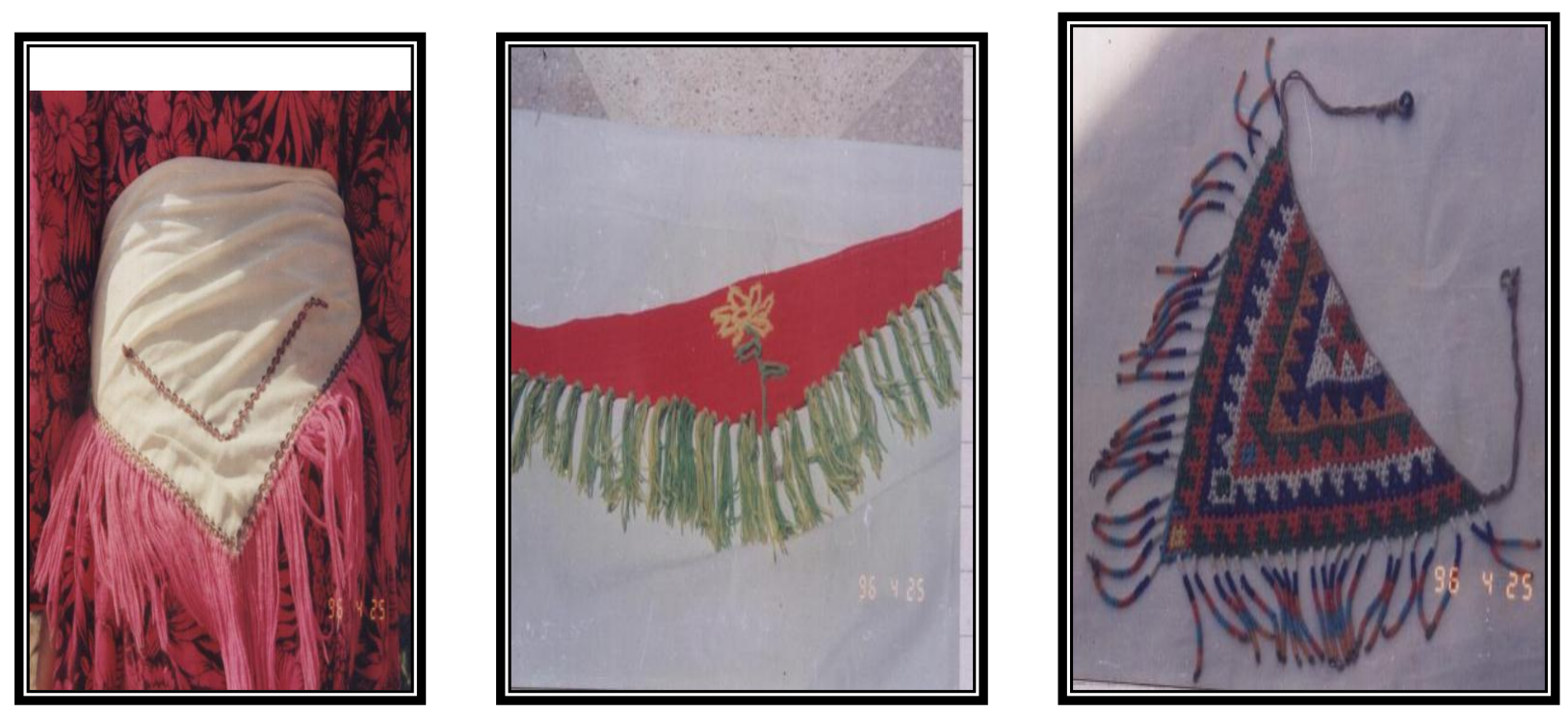

مصدر الأقتباس 
نجدة إبر اهيم محمود ماضى: دراسه تحليليه للأزياء الشعبيه فن منطقه برج العرب بكحافظة الأسكندرية والأستفاده منها لإقتباس أزياء نسائيه معاصره 


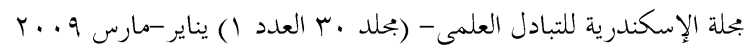


اجابتهن لا او افق بلغت(صفر - qY\%)كما بلغت نسبه استجابه هذا

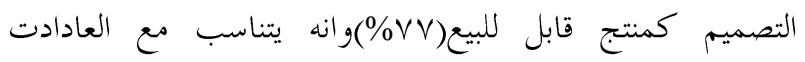
و التقاليد بنسبه (\% (\%).

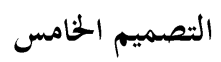

في العبارات التي توضح استجابات المستهلكين بند ان نسبه

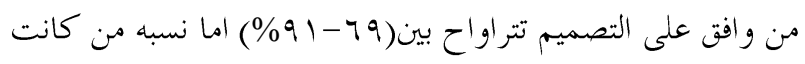

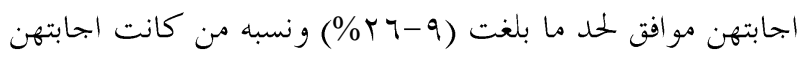
لا اوافق بلغت(r - (1\%) عند خانة لا اوافق، كما ان هذا التصميم يصلح كمنتج قابل للبيع واقبال الجمهور بنسبة 7 ه\%، وانه

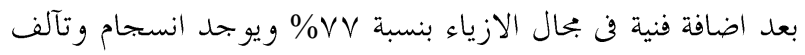
بين اجزاءه بنسبة 99\%

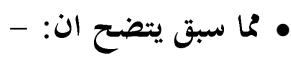
جميع التصميمات اقبالا من المستهلكين ولكن بنسب متفاوته، ويرجع ذلك الى الذوق الشخصى لكل فرد للتصميم الذى يتلائم مع شخصيته وميوله مما يحقق اهداف البحث.

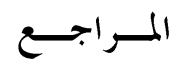

1- إبر اهيم مصطفى( .94 ()- المعجم الوسيط- ج- 1 - مطبعة مصر.

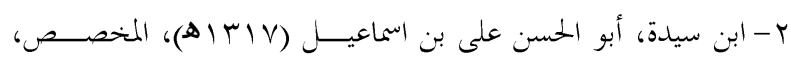

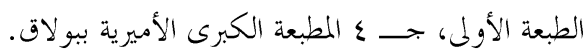

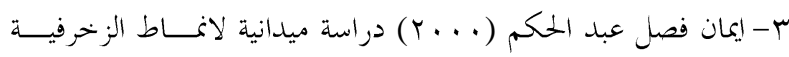

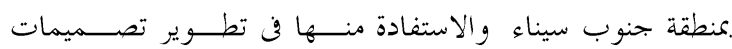
للاقمشة الوبرية ذات المستويات المختلفة باسلوب الضم المتباعدرسالة دكتور اه - كلية الفنون التطبيقة - جامعة حلوان.

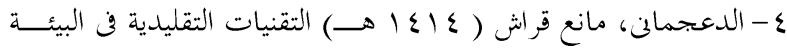

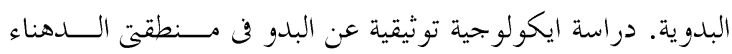
والصمان. المملكة العربية السعودية. الرياض: دار العاصمة.

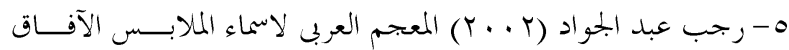

$$
\text { العربية القاهرة . }
$$

7- سامية أحمد الجارحى (ع 999 (1) تأثير الحضارات المختلفة على الأزياء وزخارفها في جنوب سيناء - رسالة ماجستير غير منشورة - كلية

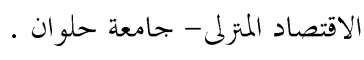

تم عرض الأستبانه على مجموعه من المستهليكين من الفتيات التى ترواحت اعمارهن بين 1 ا - هץ سنه وعددهن هب فتــاه وتم حساب التكرارت والنسب المئويــهـ لأسـتجابات المســتهليكين للتصميمات المقتبسه وهذا ما يوضحه الجحدول التالى:بدراسه الجدول رقم ( ال السابق يتضح ما يلى:التصميم الأول فن العبارات التي توضح استجابات المستهلكين بحد ان نسبه من

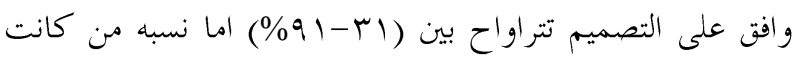
اجابتهن مو افق لحد ما بلغت (7-9 §\%) و ونسبه من كانت اجابتهن لا اوافق بلغت ( صفر - YYY\%) ما يؤكد ان هذا التصميم يلقى اقبالا من المستهلكين وانه يناسب الفترة الصباحية بنسبة (ابץ\%) ويوجد انسجام وتآلف بين اجزائه بنسبة (r/\%) ويمثل اضافة جديدة في بحال ازياء الموجودة بالاسواق بنسبة (ع وه\%) و والوانه وخاماته تتلائم مع الموضة الحديثة بنسبة (7 م\%\%). • التصميم الثالن في العبارات التي توضح استجابات المستهلكين بند ان نسبه

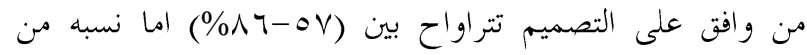

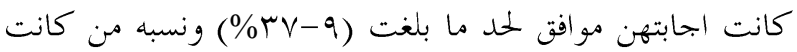

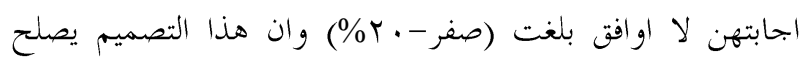

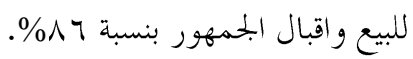

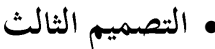

في العبارات التي توضح استجابات المستهلكين بند ان نسبه

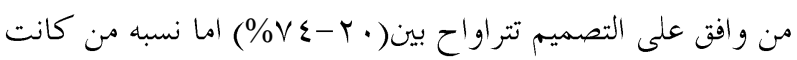

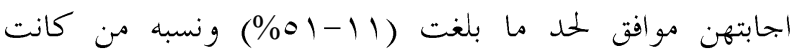
اجابتهن لا اوافق بلغت(r - V० كما بلغت نسبة استجابة هذا التصميم كمنتج قابل للبيع 9٪\% و وانه يمثل اضافة جديدة

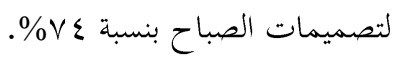

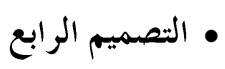

في العبارات التئ توضح استجابات المستهلكين بند ان نسبه

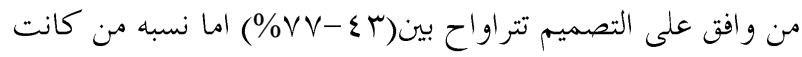

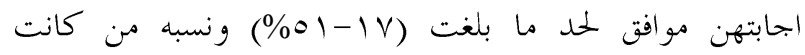


1 ا-محمد شفيق غربال (1970 19) الموسوعة العربية الميسرة، مؤ سســـة

$$
\text { فرانكلين. }
$$

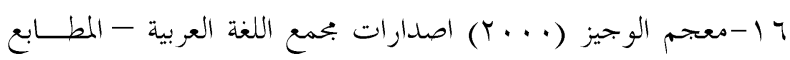

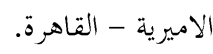

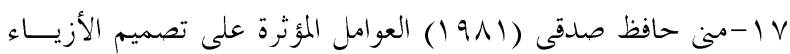

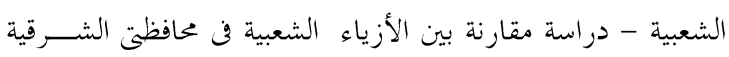

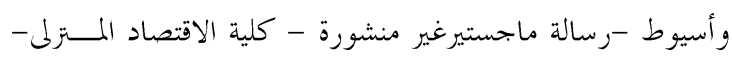
جامعة حلو ان.

1 ا-منير البعليكى (1999 1) قاموس المورد القريب، دار العلم للملايين،

$$
\text { بيروت. }
$$

9 (1-نبيل صبحى حنا (ع ا9 1) المختمعات الصحر اوية في الوطن العربى ( دراسة نظرية وميدانية )- دار المعارف - الطبعة الأولى.

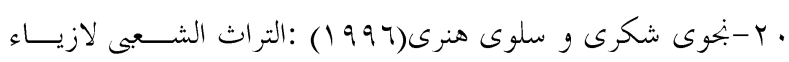
الرجال في سوريا و اقتباس تصميمات منها تنفد بأسلوب التشكيل على المانيكان بحث منشور بمجلة علوم وفنون -العدد التالث البحلد

$$
\text { الثامن يوليو }
$$

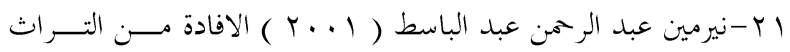
الشعبة في محافظتى دمياط ومرسى مطروح لتصنيع ملابس عــــائس الطفل لتنمية ثقافته الفنية - رسالة دكتوراه كلية الاقتصاد المترلى -

جامعة حلوان.

$$
\text { مر اجع من الأنترنت:- }
$$

الموقع الألكترون لهيئه البختمعات العمر انيه الجحديده على الأنترنت

(http://www.urban-comm.gov.eg)
- Vامية أحمد الجارحى (999 199 ) إمكانية الاستفادة مسن زخهـارف

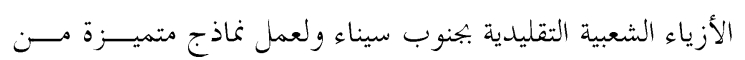
العر ائس تلائم بحال السياحة في مصر - رسالة دكتوراه غير منشورة - كلية الاقتصاد المترلى - جامعة حلو ان.

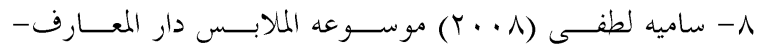

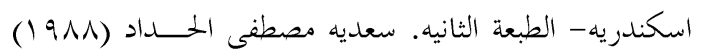

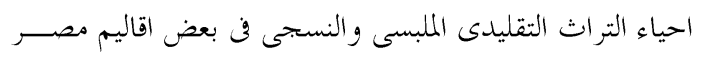

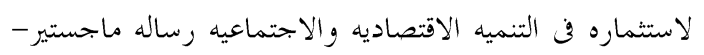

$$
\text { كليه الزراعه- جامعه الاسكندريه. }
$$

9- سعديه مصطفى الحداد( 9 9 1 ) ) احياء التراث التقليـــى الملبســى و النسجى في بعض اقاليم مصر لاستثماره في التنميـــه الاقتصــاديه والاجتماعيه رساله ماجستير - كليه الزراعه- جامعه الاسكندريه

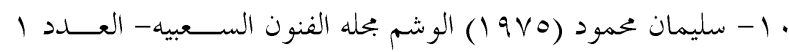
الهيئه المصريه للكتاب- القاهرة.

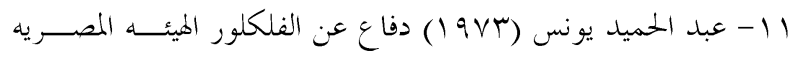
العامه للكتاب- القاهرة .

T ا - عبد المنعم سيد عبد العال ( IVV I ) معجم الالفاظ العامية المصرية ذات الاصول العربية - مكتبة النهضة - القاهرة.

"ا - فوزى العنتيل ترجمة ( IV I ) بين الفولكلور والثقافة الشعبية " الهيئة المصرية العامة للكتاب- القاهرة ع ا-لويس معلوف قاموس المورد (199V 19.)- دار العلــم للملايسـينبيروت 


\title{
Analytical Study of The Popular Fashion in The Area of Burg Al Arab, Alexandria Governorate, and Use of Contemporary Women 'S Fashon Is Offline
}

\author{
Nagda Ibrahim Mady \\ Cast light on an important part of our Egyptian \\ representative in the region an important area of Burg \\ el-Arab in Alexandria through the study of patterns of \\ popular supplements, clothing and uniform designs to \\ design modern innovation and adapted this popular \\ clothing and accessories including decorations for the \\ enrichment of those designs. \\ The search followed the approach used descriptive \\ and historical researcher, historical books, \\ encyclopedias and specialized technical and scientific \\ research in the area where they were making ten \\ innovative designs adapted from the popular clothing \\ and accessories in the search area and the addition of \\ effects and decorations and accessories for them.
}

